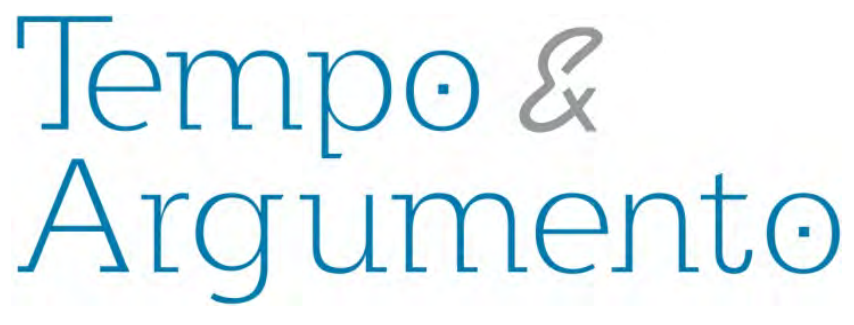

\title{
Por uma história fotográfica dos acontecimentos contemporâneos, Rio de Janeiro, 30 de junho de 1987
}

\begin{abstract}
Resumo
Este artigo analisa o acontecimento histórico - "quebraquebra" no Centro do Rio, em junho de 1987 - por meio das fotografias veiculadas em 5 jornais do Rio de Janeiro e 1 de Niterói, no dia seguinte ao acontecimento, 10 de julho de 1987. Observa-se, preliminarmente, a origem da preocupação historiográfica, em que os acontecimentos foram reabilitados para a análise histórica, sobretudo pela forma como a fotografia foi convocada para seu estudo. A reconstrução da história fotográfica do evento de 1987 apoia-se nas noções de fotografia pública e espaço público visual, para analisar os sentidos do acontecimento produzidos pelos jornais da cidade do Rio de Janeiro e avaliar o papel desempenhado pelo fotojornalismo na produção do fato histórico.
\end{abstract}

Palavras-chave: Fotografia na Historiografia; Rio de Janeiro (RJ) - História - 1987; Espaços Públicos - Rio de Janeiro.

\author{
Ana Maria Mauad \\ Doutora em História pela Universidade Federal \\ Fluminense - UFF. Estágio Pós-doutoral na \\ Universidade de São Paulo - USP. Professora do \\ Programa de Pós-Graduação em História da \\ Universidade Federal Fluminense - UFF. \\ Brasil \\ anammauad@gmail.com
}

\section{Para citar este artigo:}

MAUAD, Ana Maria. Por uma história fotográfica dos acontecimentos contemporâneos, Rio de Janeiro, 30 de junho de 1987. Revista Tempo e Argumento, Florianópolis, v. 8, n. 17, p. 90 - 133. jan./abr. 2016. 


\title{
For a photographic history of contemporary events, Rio de Janeiro, June 30, 1987
}

\begin{abstract}
This article analyzes the historical event - a "riot" in Downtown Rio, in June 1987 - by means of photographs published in 5 newspapers from Rio de Janeiro and 1 from Niterói, the day after the event, July 1, 1987. We preliminarily observe the origin of the historiographical concern, where the events were rehabilitated for a historical analysis, above all due to the way how photography was called upon to study them. The reconstruction of the photographic history of the 1987 event is based on the notions of public photography and visual public space, in order to analyze the meanings of the event produced by the newspapers from Rio de Janeiro and evaluate the role played by photojournalism in the making of a historical fact.
\end{abstract}

Keywords: Photography in historiography; Rio de Janeiro (RJ) - History - 1987; Public Spaces - Rio de Janeiro.

Em 30 de junho de 1987, as passagens de ônibus na cidade do Rio de Janeiro haviam aumentado 50\%, passando de $\mathrm{Cz} \$$ 4,80 para $\mathrm{Cz}$ 7,20. O aumento autorizado pela liminar de um juiz estadual, na segunda-feira, dia 29/06, foi repassado no dia seguinte à população. Sem qualquer aviso prévio, as passagens foram reajustadas pelos empresários das empresas de ônibus. No meio da semana, milhares de trabalhadores que se deslocavam de diferentes regiões das zonas metropolitanas do Grande Rio, por meio de trens e barcas, foram surpreendidos ao chegar no Centro da cidade, pelo repasse desavisado. A surpresa inicial, transformada em indignação pelo aumento abusivo, foi crescendo e assumindo proporções de revolta, que se estendeu ao longo do dia 30 de junho de 1987, e converteu o Centro da cidade do Rio de Janeiro numa praça de guerra.

O motim urbano, acompanhado de quebra-quebra e queima de vários ônibus, seguiu o roteiro de situações de confronto entre população e autoridades: movimentação de grande massa de pessoas pelas ruas sem destino certo, focos de indignação que se desdobram em desespero, ao que se seguem a repressão das forças policiais do estado e 
iniciados em 8 de janeiro de 2016, no Rio de Janeiro, mas sobretudo em São Paulo. Em todas essas situações, o registro fotográfico deixou pistas importantes para se compreender a complexidade da experiência histórica que caracteriza tais acontecimentos.

Em situações distintas, a prática fotográfica cumpre papel fundamental na elaboração de narrativas sobre os acontecimentos, que competem com outras narrativas, de caráter verbal ou oral, na compreensão do tempo presente. Característica reconhecida por Walter Benjamin ao defender a fotografia como síntese do acontecimento histórico, na leitura de Lissovsky (2014, p. 7), "a representação figural da imagem dialética capaz de contrair presente, passado e futuro em um momento singular".

Leitura que leva o autor a afirmar que fotografia é história, a história fotográfica de passados possíveis de se tornarem futuro. Lissovsky inspira-se na ideia de Benjamin, segundo a qual as fotografias seriam capazes de aninhar o futuro em minutos únicos (BENJAMIN, 1931, 1987), para refletir que:

[...] o futuro habita as imagens do passado como um "ovo" em seu ninho. Está encoberto por uma casca e seu conteúdo, portanto, só pode ser adivinhado (por fotógrafos e historiadores, entre outros sucessores dos adivinhos). Porém, enquanto isso não acontece, o futuro está sendo chocado. Está lá, adormecido, à espera do momento de seu despertar, quando a casca se rompe e ele é finalmente reconhecido. Esse momento é sempre um agora. O agora de uma reciprocidade entre passado e futuro que não tem data marcada para acontecer. $O$ agora de uma correspondência, o agora de um reconhecimento. É desde um agorafuturo que a fotografia que contém nossa imagem de passado está à espera. (LISSOVSKY, 2011, p. 9)

As inspirações benjaminianas de Lissovsky nos orientam a propor uma abordagem em que fotografia e a história tornam-se indissociáveis. Perspectiva que rompe tanto com os tradicionais usos ilustrativos das imagens fotográficas quanto com a sua percepção como fonte histórica, aproximando-se à perspectiva de uma história visual, em que as imagens, objeto e fonte, atuam como plataformas de observação da sociedade 
quebra no Centro do Rio, em junho de 1987 - por meio das fotografias veiculadas em 5 jornais do Rio de Janeiro e 1 de Niterói, no dia seguinte ao acontecimento, $1^{\circ}$ de julho de 1987. Observa-se, preliminarmente, a origem da preocupação historiográfica, em que os acontecimentos foram reabilitados pelo viés da renovação historiográfica, mas sobretudo pela forma como a fotografia foi convocada ao seu estudo. Destacam-se nessa parte as considerações sobre fotografia pública e as possibilidades conceituais da noção de espaço público visual.

A reconstrução da história fotográfica do evento de 1987 apoia-se nesses dois princípios para analisar a narrativa visual dos acontecimentos veiculada nos jornais da cidade do Rio de Janeiro e avaliar o papel desempenhado pelo fotojornalismo na produção do fato histórico.

\section{O acontecimento, uma preocupação historiográfica}

Originariamente apresentado como comunicação no XIV Simpósio Nacional da Associação Nacional de História (ANPUH), realizado em julho de 1987, em Brasília, o estudo sobre o quebra-quebra dos ônibus do Rio de Janeiro recebia o extenso título: “Possibilidades de uma análise histórico-semiótica: o uso da fotografia como fonte histórica". Sua recepção por parte de uma plateia de estudantes de pós-graduação, professores de história e historiadores não foi das melhores, tendo em vista que toda a análise partia da mensagem fotográfica produzida sobre um acontecimento corrente, que nem sequer havia descansado nos arquivos, com documentos cujo valor como fonte histórica era muito controverso. Tratava-se, portanto, de uma pesquisa de comunicação, não de História, esse foi balanço final da apresentação.

Passados, praticamente, 30 anos do Simpósio de Brasília, o panorama da historiografia mudou significativamente para o que interessa a esta abordagem, sobretudo em dois aspectos que dizem respeito ao estudo do acontecimento em História: o aprofundamento dos debates sobre história contemporânea, através da 
No âmbito da renovação dos estudos de história contemporânea, a edição de 1974 de "Faire l'histoire", coletânea em três volumes, organizada por Pierre Nora e Jacques Le Goff, incluiu, no volume "Novos problemas", o clássico texto de Pierre Nora, “O retorno do fato". Nesse texto, o autor elaborou uma concepção transformada da noção de acontecimento:

Contudo, nenhuma época se viu, como a nossa, viver seu presente como já possuído de um sentido "histórico". E somente isso seria suficiente para dotá-la de uma identidade, para libertar a história contemporânea da sua imperfeição. As guerras totais e as transformações revolucionárias, a rapidez das comunicações e a penetração das economias modernas nas sociedades tradicionais, em resumo, tudo o que se costuma entender por mundialização assegurou uma mobilização geral das massas que, por trás do front dos acontecimentos, outrora representavam os civilizados da história; ao passo que os movimentos de colonização e depois de descolonização, integravam à historicidade de tipo ocidental sociedades inteiras que, ainda ontem, dormiam no sono dos povos "sem história" ou no silêncio da opressão colonial. Essa vasta democratização da história, que fornece ao presente a sua especificidade, possui sua lógica e suas leis: uma delas - a única que aqui desejamos isolar - é que a atualidade, essa circulação generalizada da percepção histórica, culmina num novo fenômeno: o acontecimento. (NORA, 1979 p. 180)

Apoiado na percepção de que a cultura de mídia transformaria a ideia de tempo e espaço em um mundo cada vez mais dominado pelos meios, Nora avaliava que a imprensa, o rádio, as imagens e, atualmente, a internet, tornar-se-iam a própria condição de existência dos acontecimentos. Através dos meios de comunicação, os acontecimentos ganhariam o reconhecimento público, e completa o autor:

"com muito mais força na medida em que os media impõem imediatamente o vivido como história, e que o presente nos impõe em maior grau o vivido. Uma imensa promoção do imediato ao histórico e do vivido ao lendário opera-se no momento mesmo em que o historiador se encontra confuso nos seus hábitos, ameaçado nos seus poderes, confrontado com o que se aplicava, em outro lugar, a reduzir" (NORA, 1979, p. 183).

Na crítica contundente de Nora ao acontecimento moderno, "sem historiador e feito da participação afetiva das massas" (NORA, 1979, p. 185), o autor o coloca como única forma de as massas, nas sociedades democráticas, participarem da vida pública. Um 
A multiplicação exponencial de acontecimentos na cultura midiática globalizada levaria àquilo que Nora definiu do seguinte modo: "estado de superinformação perpétua e de subinformação crônica caracteriza nossas sociedades contemporâneas" (NORA, 1979, p. 187). Entretanto, residiria no paradoxo do acontecimento, algo que acontece sem de fato acontecer, o caminho para a sua apreensão pela história:

O deslocamento da mensagem narrativa nas suas virtualidades imaginárias, espetaculares, parasitárias, tem como efeito assinalar, no acontecimento, a parte do não factual. Ou melhor, de fazer do acontecimento o lugar temporal e neutro da emergência brutal, isolável de um conjunto de fenômenos sociais surgidos das profundezas e que sem ele, continuariam enterrados nas rugas do mental coletivo. $O$ acontecimento testemunha menos pelo que traduz do que pelo que revela, menos pelo que é do que pelo que provoca. Sua significação é absorvida na sua ressonância; ele não é senão um eco, um espelho da sociedade, uma abertura. (NORA, 1979, p. 188)

Portanto, a chance do historiador do presente seria a de mergulhar no paradoxo do acontecimento e tensionar a relação entre real e imaginário nas sociedades contemporâneas. Assumindo o desafio de pensar o acontecimento como um feixe de temporalidades, ou, como queria Benjamin, uma imagem dialética, promovendo a leitura a contrapelo da história (BENJAMIN, 1987).

O texto de Nora inauguraria um momento importante de renovação nos estudos sobre a história contemporânea, no âmbito internacional, mas que só seria assimilada no Brasil nos anos 1990, com valorização da história oral e do tema da memória para o estudo dos regimes ditatoriais. A discussão sobre os usos do passado passaria, a partir de então, a nortear o debate sobre a história do presente, no Brasil, incorporando à renovação da história política o estudo da história das representações culturais e das culturas políticas (PÔRTO, 2007 e VARELLA, 2012).

O estudo das imagens no campo dos estudos históricos, e sobretudo o da fotografia e do cinema, também desempenhou um papel decisivo na compreensão da centralidade das representações culturais para a compreensão do mundo contemporâneo (KNAUSS, 2006, 2008; MAUAD, 2016). Do ponto de vista da relação entre 
têm investido na sua relação com o acontecimento moderno (STIMSON, 2007; HARIMAN, LUCAITES, 2007; MAUAD, 2008a). Como indicado por Nora, o acontecimento ocupa um lugar central na cultura liberal das democracias ocidentais, assegurando uma representatividade aos que dele participam como sujeitos da cena pública. Entretanto, a cena só se torna pública na medida em que é registrada por meio de um dispositivo técnico, uma câmera. A câmera, sobretudo a fotográfica, possui a capacidade de estancar o fluxo do tempo que passa, registrando a vida em cenas.

Cenas que se multiplicam e replicam cenas já vistas, num processo contínuo de produção de imagens que se assemelham às imagens antes já vistas, aquilo que a historiografia moderna sobre fotografia denominou de foto-ícone (HARIMAN, LUCAITES, 2007; MAUAD, 2008a). Uma imagem que vale mil palavras, uma imagem que sintetiza o acontecimento, uma imagem que possui uma história por detrás, são noções corriqueiras a ser enfrentadas quando se opera com o conceito de foto-ícone. Na esteira das reflexões de Nora, o foto-ícone potencializaria o paradoxo do acontecimento, algo que acontece sem de fato acontecer, produzindo ele próprio o acontecimento-imagem. Nesse registro interpretativo, não há uma história por detrás das imagens, mas uma história instituída pelas imagens. A história das imagens é o que o historiador moderno deve enfrentar criticamente (MENESES, 2003 e 2005 KNAUSS, 2006 e 2008).

Mães migrantes, presidentes, soldados, crianças desvalidas apresentam no espaço público visual uma existência alienada dos seus próprios corpos e de sua condição histórica. O contrato social da fotografia, para seguir a expressão de Ariella Azoulay, deveria garantir ao fotografado a posse da sua imagem (AZOULAY, 2008, 2012), entretanto, a multiplicação de imagens replicantes em foto-ícones orienta cada um para o encontro com o seu duplo.

A análise dos acontecimentos produzida pelo moderno fotojornalismo requer que se reconheça que os circuitos sociais que definiram essa prática fotográfica produziram uma fotografia pública que constituiu uma esfera pública visual ao longo do século XX. 
A produção histórica da fotografia pública, ao longo do século XX, associou-se, por um lado, à constituição da sociedade burguesa, liberal e democrática, e, por outro, ao apoio à propaganda de regimes ditatoriais e fascistas. Sua prática se constitui no âmbito de circuito social, proveniente da cultura dos meios e das mediações, composto pelas agências de produção das imagens governamentais (órgãos ligados ao Estado que possuem a função de registro e arquivo da sua ação sobre o espaço público; bem como as assessorias de imprensa e propaganda que cumprem a função de publicizar a ação do Estado como o principal organizador das relações sociais no espaço público), pelas agências da grande imprensa e pelas agências independentes que operam conjuntamente aos movimentos sociais.

Em compasso com a configuração de uma cultura visual plural e diversificada, ao longo do século XX, a questão social emergiu na cena pública, de distintas maneiras e em diferentes locais, alimentada pelos movimentos sociais e políticos de procedências e tendências também variadas: do movimento operário às demandas de liberdade sexual, passando pelas lutas pelos direitos civis, movimentos pós-coloniais etc., tudo isso captado por profissionais atentos ao calor dos acontecimentos. Tais imagens compõem um catálogo, no qual surge uma história redefinida pelo estatuto técnico próprio ao dispositivo da representação: a câmara fotográfica. Nesse outro tipo de escrita da história, o local de sua produção (as agências de produção da imagem: família, Estado e imprensa) e o sujeito da narrativa (os fotógrafos) dividem com os institutos históricos e as academias literárias a tarefa de imaginar a nação e instituir os lugares de sua memória. Assim, a experiência fotográfica do novecentos redefiniu as formas de acesso aos acontecimentos históricos e sua inscrição na memória pública, a ponto de podermos contar a história do século XX através de suas imagens. Ao mesmo tempo, a produção de imagens fotográficas voltadas para o registro de processos, situações e sujeitos históricos contribuiu significativamente para a configuração dos sentidos atribuídos ao espaço público na contemporaneidade.

A fotografia pública, ao longo do século passado, pode ser compreendida em dois rumos: o da prática artística e o da prática documental. No primeiro caminho, o da prática 
princípio realista. Assim, a fotografia pública na sua dimensão de prática artística esteve comprometida tanto com a pedagogia do sujeito e o cultivo do olhar quanto com o engajamento de públicos à percepção crítica do mundo visível.

No segundo caminho, como registro documental, a fotografia pública esteve associada às agências governamentais, à imprensa ilustrada e à produção das notícias, agindo como janelas que se abriam para o mundo, figurando-o da forma mais realista. Ainda nesse segundo rumo ou tendência, a produção fotográfica novecentista associouse às práticas de registro social, servindo para documentar as condições de vida de diferentes setores sociais, como os deslocamentos humanos, conflitos e situações-limite.

Ao observar o ambiente das publicações ilustradas, percebemos a conformação de um espaço público visual que, desde finais do século XIX e ao longo do século XX, se associa ao processo de internacionalização da cultura burguesa. Nesse movimento, as revistas ilustradas e jornais diários apresentam-se como plataformas de lançamento de imagens que se espalham no tempo e no espaço da experiência histórica. Mais do que evidências do vivido, as fotografias na imprensa caracterizam-se por agenciarem múltiplas versões dos acontecimentos e plasmarem as memórias históricas.

As considerações em torno da elaboração de um espaço público visual associam-se à existência de uma cultura visual em que os meios de produzir imagens, fixas e em movimento, não só criam representações sobre o mundo visível, num movimento de dar a ver e de conhecer o mundo representado em imagens, mas instituem, elas mesmas, um mundo visível por meio das imagens. Entretanto, há que se avaliar as dimensões históricas das culturas visuais e as economias de trocas simbólicas que estabelecem entre os diferentes grupos sociais, para compreendermos as formas que esse espaço público visual assume.

Em uma coletânea de ensaios intitulada "O ornamento da massa" (KRACAUER, 2009), o teórico alemão Siegfried Kracauer reuniu um conjunto de artigos publicados ao longo das décadas de 1920-30, quando ainda vivia na Alemanha e compartilhava do mesmo ambiente intelectual de Walter Benjamin, Theodore Adorno e os demais 
com o mesmo título, escrito em 1927 e publicado no prestigioso periódico alemão Frankfurter Zeitung.

Em ambas as reflexões sobre fotografia, Kracauer (2009) discute a questão do realismo fotográfico e estabelece os princípios de reconhecimento da relação entre a imagem fotográfica e as formas de reificação capitalistas, mas no ensaio incluído na obra "O ornamento da massa", o autor dedica especial interesse às fotografias publicadas nas revistas ilustradas.

Nessa reflexão, Kracauer (2009) apresenta a fotografia como um dos "objetos internos e externos" da cultura de massa capitalista. Relaciona o princípio que orienta os usos e funções da fotografia aos mesmos que orientam a percepção da história oitocentista, apoiada no historicismo mecânico de mostrar a "vida tal como ela aconteceu":

Em resumo, os seus representantes [do historicismo] pensam poder esclarecer de modo puro qualquer fenômeno a partir da sua gênese e acreditam apreender também a realidade histórica ao reconstituir sem lacunas a série de acontecimentos na sua sucessão temporal. A fotografia oferece uma continuidade espacial, o historicismo quer preencher a continuidade temporal. De acordo com o historicismo, o espelhamento completo de uma sequência intratemporal contém simultaneamente o sentido de conteúdo que ocorreu no mesmo período [...] Para o historicismo, trata-se de fazer uma fotografia do tempo. Esta fotografia do tempo corresponderia a um filme gigantesco que representasse universalmente os acontecimentos relacionados. (KRACAUER, 2009, p. 66)

A preocupação em estabelecer paralelos entre os meios fotográficos e a realidade histórica, como reconhece o próprio Kracauer (2009), em nota em seu livro, o acompanharia até os seus escritos dos anos 1960, quando escreveu a obra História: as últimas coisas depois da última, publicada após a sua morte, em 1971 (GINZBURG, 2008). Essa preocupação critica a perspectiva do realismo mecanicista, em que se subtrai a mediação crítica do ato de conhecimento e as determinações sociais que levam à própria produção da vida social.

Ao se debruçar sobre a fotografia, Kracauer (2009) mira a História e as formas de subjetivação das experiências com o tempo - duração, extensão, diferença e ruptura. Ao 
se ocupa de datas, pula sobre os anos ou dilata a distância temporal. [...] A seleção foi feita desta e não de outra maneira, pois as disposições e as intenções exigem o recalque, a falsificação e a alteração de valores do objeto [...]. Não importa quais cenas um indivíduo recorda: elas querem dizer algo que se relaciona a ele sem ele precisar saber o que elas querem dizer. Elas são conservadas justamente em relação ao que querem lhe dizer" (KRACAUER, 2009,p. 67).

A outra dimensão é essencial, compacta e reveladora. O seu reconhecimento pela consciência liberta coloca o sujeito em face da sua própria história:

\begin{abstract}
A significação das imagens da memória está acoplada a seu conteúdo de verdade. [...] Encontrar a verdade só é possível à consciência liberta que pondera o demoníaco das pulsões. Os traços dos quais se recorda estão em relação ao que se reconhece como verdade, suscetível de se manifestar neles ou de ser deles excluídos. A imagem, que contém estes traços, é distinta de todas as outras imagens da memória; com efeito, esta não conserva como as outras uma abundância de recordações opacas, mas os conteúdos que concernem ao que é reconhecido como verdade. A esta imagem, que podemos com pertinência chamar de última, devem se reduzir todas as imagens de memória, pois é só nela que perdura o inesquecível. A última imagem de um indivíduo é a sua própria história. Esta omite todos os signos e determinações que não estão em relação significativa com a verdade designada pela consciência liberta. A maneira como o indivíduo a representa não depende puramente de sua própria natureza, nem tampouco da coesão aparente da sua individualidade; há, portanto, somente as partes de seus elementos que entram na sua história. (KRACAUER, 2009, p.68)
\end{abstract}

A busca da verdade pela consciência crítica atua como um redutor de imagens supérfluas até a imagem essencial, em que se condensa a experiência do indivíduo em história. A imagem-síntese que revela a dimensão histórica das experiências individuais encontra na fotografia um possível meio de expressão. Isso porque a fotografia, ao mesmo tempo em que captura a realidade vivenciada no ato fotográfico, a despoja de suas referências de conteúdo subjetivo. A captura da fotografia não dá conta do sentido que as vivências inscrevem na memória como imagem, as imagens da memória olham para as fotografias como restos de uma experiência esvaziada pela falta de conteúdo memorável, "a soma que aniquila enquanto o reproduz: o ser humano não existiria se 
Nas considerações de Kracauer sobre memória e fotografia, nos anos 1920 e 30, subjaz a busca de uma concepção da história que supere o corte individualista das tradicionais filosofias oitocentistas. O deslocamento das imagens de memória do retrato burguês de estúdio que circulava nos álbuns de família, como memória encapsulada pelo sujeito individual - "Sob a fotografia de um indivíduo está enterrada sua história sob um manto de neve" (KRACAUER, 2009, p.68) -, para a variedade de imagens contemporâneas, sobretudo nas revistas ilustradas, impõe ao autor um desafio crítico: "O contemporâneo acredita ver na fotografia a própria diva do cinema. [...] O que significa que a fotografia atual cumpre o papel de mediadora, é um signo ótico da diva que se trata de reconhecer. Se sua característica decisiva é ser sobrenatural, deve-se duvidar ao final." (KRACAUER, 2009, p. 71)

A princípio, a variedade de imagens que povoa os semanários ilustrados que circulavam nos anos 1920 provoca no autor uma reação de rejeição e conflito, que o leva a denunciar enfaticamente a produção em massa de imagens em afirmação contundente:

A intenção das revistas ilustradas é reproduzir completamente o mundo acessível ao aparelho fotográfico [...] Nunca houve uma época tão bem informada sobre si mesma, se ser bem informado significa possuir uma imagem das coisas iguais a elas no sentido fotográfico. [...] Nas revistas ilustradas o público vê o mundo que as revistas impedem de realmente perceber. O contínuo espacial segundo a perspectiva da câmera fotográfica recobre o fenômeno espacial do objeto reconhecido, e sua semelhança desfigura os contornos de sua 'história'. [...] Nas mãos da sociedade dominante a invenção das revistas ilustradas é um dos mais poderosos instrumentos de greve contra o conhecimento. [...] A ideia-imagem cancela a ideia, a nevasca de fotografias trai a indiferença em relação ao que as coisas querem dizer. [...]. Pois o próprio mundo adquiriu um 'rosto fotográfico', pode ser fotografado, pois este se funde no contínuo espacial que se forma com os instantâneos. Pode depender apenas de uma fração de segundo, o que é suficiente para a exposição do objeto, para que um desportista se torne célebre, segundo os fotógrafos sob o comando das revistas ilustradas [...] Nas revistas ilustradas, o mundo torna o presente fotografável e o presente fotografado torna-se inteiramente eternizado. Parece ter extirpado a morte, mas na realidade a fotografia a abandonou. (KRACAUER, 2009, p. 76)

Observavam-se nessa denúncia aspectos do argumento que servirá de base para a conversão crítica da fotografia moderna: a fotografia como um arquivo universal de 
valorização do efêmero das celebridades. A eternização de um presente contínuo nas fotografias modernas, não mais ameaçado pela iminência da morte, transformou a imagem-memória em imagem-arquivo.

Os próprios contornos dessa sociedade aparecem eternizados como despojos de uma civilização passada, pelas fotografias nas revistas ilustradas, oferecendo à consciência emancipada a chance de produzir uma crítica a partir de seus próprios termos, e experimentar sobre elas o seu próprio poder: "A guinada em relação à fotografia representa o jogo de azar da história” (KRACAUER, 2009, p.78). Portanto, apesar de criticar a massificação que a fotografia moderna sofre, sobretudo através da sua veiculação nas revistas ilustradas, e posteriormente nos jornais diários, Kracauer (2009) considera a função arquivo da fotografia, a capacidade de expor o fundamento natural do mundo - para além da memória subjetiva -, um mundo que se torna mundo pela imagem fotográfica.

A argumentação de Kracauer se desenvolve em diálogo com a fortuna crítica que se constitui no âmbito do marxismo ocidental dos anos 1920-30. Dentre os principais interlocutores desse diálogo encontra-se Walter Benjamin. No clássico "Pequena história da fotografia", de 1931, Benjamin indaga sobre o futuro das imagens fotográficas no sistema visual que se apresenta na virada do XIX para o XX. O destaque fundamental associa-se à crise da percepção, potencializada pela emergência de capacidade criativa e de engenho artístico relacionado ao advento da racionalidade técnica como modo prioritário de se operar sobre o mundo, e da tecnologia como princípio civilizatório.

O ponto central dessa reflexão reside na relação que o sujeito moderno estabelece com o mundo visível pela mediação estética pautada nos princípios de um mundo tecnológico. O que se passa com essa relação quando a fotografia deixa de ser objeto de apreciação e passa a criar um padrão de representação compartilhado por todos os sujeitos e, portanto, naturalizado como a representação por excelência do real imaginado? Contra a arte que se apresenta como sublime se opõe a representação técnica que descansa o olhar e sublima a consciência da visão. Assim indaga sobre a 
preocupação do pensador em inventariar e sistematizar posições em torno do tema da modernidade. O que se apresenta na seleção desses pequenos trechos notáveis é, justamente, a centralidade da fotografia na economia visual que se organiza a partir da segunda metade do século XIX. Essa economia visual insere-se num patamar civilizatório, no qual o capitalismo surge como condição histórica. Assim, as experiências que se desenrolam dentro dessa economia visual estão apoiadas na sua radical historicidade capitalista. Daí a perda da aura ser um problema para a percepção estética, que se vê ameaçada pela naturalização da imagem técnica massificada, já identificada por Kracauer no texto de 1927. A perda da trama espaço-temporal - deslocamento e distanciamento relacionados à experiência aurática - acaba por aprisionar no tempo/espaço da condição social posições de classe que são históricas e, portanto, passíveis de serem transformadas.

A condição histórica que se apresenta na era da reprodutibilidade técnica tem como conceito-chave o progresso, de onde se desdobram noções fundadoras do indivíduo moderno: técnica, velocidade, conforto, movimento, beleza, individualidade tanto para o produtor de imagens quanto para o seu receptor. Define-se um mesmo universo de signos visuais que orientam a elaboração de linguagens e a sua compreensão. O que se pode avizinhar desses pequenos trechos sobre a sociedade que o produziu e ao mesmo tempo assimilaram essas ideias e conceitos? Um projeto benjaminiano para compreender a história calcado na percepção da emergência de um novo regime de visualidade, resultante da crise da representação visual clássica.

Na cultura visual própria à modernidade de natureza intermedial, as imagens técnicas migram da fotografia para o cinema, das páginas llustradas para as propagandas governamentais, dos jornais diários para as assessorias de imprensa, dos relatórios científicos para as reportagens fotográficas, dos registros documentais para a ficção. Os circuitos sociais de produção, circulação, consumo e agenciamento das imagens técnicas - fotográficas, cinematográficas e videográficas -, da cultura visual no novecentos, orientaram conformações possíveis para o espaço público visual. 
As características desse espaço são marcadamente políticas e estabelecem as conexões entre cultura visual e cultura política nas sociedades ocidentais. Nas configurações políticas que o espaço público visual assumiu, ao longo do século $X X$, afastou-se da clássica oposição entre o público e privado, para se aproximar de uma dimensão do público como aquilo que é comum a um grupo, a uma classe, a um gênero etc. As disputas em torno da ocupação dos espaços públicos visuais, bem como a tentativa de impor um sentido comum arbitrado somente por um dos grupos, fazem parte da guerra de imagens que o mundo contemporâneo ainda trava.

\section{0 de junho de 1987, nos jornais diários}

Vivia-se, nesse ano, no Brasil, uma situação de tensão. Passados três anos dos comícios das Diretas Já, o movimento das ruas foi substituído pela transição pactuada em torno dos acordos da "Aliança Democrática", e com a posse de José Sarney, vicepresidente do falecido Tancredo Neves. A crise de expectativas detonada pela morte do presidente, eleito indiretamente, mas com popularidade de um pleito democrático, foi acirrada por uma sucessão de desacertos do governo empossado.

Justamente em 1987, depois do fracasso dos planos Cruzado I e II, com uma inflação de $28 \%$ ao mês, o ministro da Fazenda Dilson Funaro foi substituído por Luiz Carlos Bresser-Pereira. O ministro empossado foi sabatinado na Câmara dos Deputados, em Brasília, ao mesmo tempo que o centro carioca "pegava fogo". Em Brasília, o ministro afirmava que o "programa do PMDB não é Bíblia” e que "eu sou um animal pensante e posso rever as minhas posições. Acho que o PMDB deve repensar isto (o gatilho) e retirar esse item do seu programa". Temas como confisco salarial, outro programa ao invés do defendido pelo PMDB, moratória, foram temas levantados no debate da Câmara. Na análise da crise, "Bresser-Pereira”, que a avaliou como sem precedentes na História do Brasil, criticou os planos Cruzado I e II, pelo congelamento desigual dos preços e pelos ajustes recorrentes dos salários para acompanhar a inflação (Jornal O Estado de S. Paulo, $1^{\circ}$ de julho de 1987, p. 20).

Os anos 1980 não foram um tempo perdido (QUADRAT, 2014). A retomada do espaço público como espaço político foi a marca da Campanha das Diretas Já e dos movimentos sociais associados à retomada do Estado de direito. Entretanto, observa-se 
na imprensa que noticiou o evento no Rio de Janeiro que se tratava de uma disputa de posições em torno da legitimidade de quem e de como se ocupava o espaço público nas cidades da redemocratização pactuada. Trata-se, portanto, de enfrentar o "paradoxo do acontecimento", presente na cultura da mídia, como indicado por Nora (1979), e operar a dialética entre o real e o imaginário, a produção do fato histórico e a sua transcrição pela imprensa diária em forma de notícia.

Os jornais cariocas de grande circulação, Jornal do Brasil, O Globo, Última Hora, 0 Dia, Tribuna da Imprensa e O Fluminense, fizeram uma cobertura do acontecimento marcadamente visual. Os jornais paulistas Estado de S.Paulo e Folha de S.Paulo noticiaram, em primeira página, o evento carioca aprofundando a notícia na parte do noticiário nacional, com informações e dados transmitidos pelos repórteres da sucursal carioca. Assim, proposta por uma história fotográfica do acontecimento não exclui a compreensão dos sentidos atribuídos ao mesmo acontecimento por meio dos textos que acompanham as imagens.

Do conjunto dos jornais acima citados, todos pertencem a empresários com tradição no ramo dos jornais diários. O Jornal do Brasil, nos anos 1980, um jornal quase centenário, era uma referência na imprensa nacional com perfil liberal. Já havia passado por sua reforma gráfica e ocupava, desde 1973, a nova sede na Av. Brasil 500, pertencente à família Pereira Carneiro. Nessa época, já se posicionava favorável ao parlamentarismo e contra os cinco anos de mandato do Presidente José Sarney. À frente da editoria contava com os jornalistas Fernando Pedreira, Marcos Sá Correa e Flávio Pinheiro. O Globo, fundado em julho de 1925, por Irineu Marinho, manteve-se empresa familiar de médio porte, até os anos 1960, quando por meio do acordo com a Time-Life, a empresa da família Marinho assume o perfil de sistema de comunicação. Alinha-se politicamente no apoio ao regime militar e, no ano de 1987, apoia o governo Sarney, com perfil editorial marcadamente conservador ao comentar os eventos de 30 de junho (ASSIS, 2010).

Os jornais Última Hora e O Dia pertenciam, em 1987, ao mesmo dono, o jornalista e empresário Ary Carvalho. Amigo pessoal de Samuel Weiner, Ary Carvalho adquiriu o jornal Última Hora nos anos 1970, passando a dirigi-lo. Já O Dia, pertencente ao antigo governador do Estado da Guanabara (1971-1975), Chagas Freitas, e identificado como uma plataforma do chaguismo no estado do Rio de Janeiro, foi adquirido pelo empresário em 
1983, mantendo-se como um dos jornais mais populares do estado do Rio de Janeiro, com tiragem de 80 mil exemplares nos dias úteis e 300 mil aos domingos. Esses jornais, embora não se filiassem partidariamente ao brizolismo, defendiam teses em defesa da população que se aproximavam à perspectiva de Brizola. O jornal Tribuna da Imprensa foi fundado pelo Deputado Carlos Lacerda em 1949, para atuar como plataforma de publicação das posturas e opiniões de seu fundador. Em 1962, passou às mãos de Hélio Fernandes, jornalista combativo nos anos de chumbo, que o dirigia em 1987. Fundado em 8 de maio de 1878, o jornal 0 Fluminense é um dos jornais mais antigos em circulação no país e acompanhava, na época, a tradição conservadora das elites fluminenses.

O Estado de S.Paulo e a Folha de S.Paulo alinham-se ao modelo de grande imprensa diária que nos anos 1980 consolidaria seu perfil de empresas e conglomerados de comunicação. Do ponto de vista do posicionamento político, ambos apoiaram a transição pela via pactuada, com maior ênfase no apoio ao governo Sarney, no caso da "Folha”, e uma visada mais crítica e plural no caso do "Estadão".

Do ponto de vista ideológico, não havia discordâncias significativas entre as perspectivas dos jornais. As diferenças residiam muito mais em relação ao público-alvo e à forma de enunciação que adotavam na elaboração da notícia. As manchetes evidenciam nuances na abordagem: "Alta tarifa convulsiona o Rio" (Folha de S.Paulo); "Rio sofre o seu pior quebra-quebra” (Jornal do Brasil); "Baderna no Centro do Rio" (O Globo); “As nove horas de batalha no Rio" (Estado de São Paulo); “45 feridos e 100 prisões no Centro do Rio - Quebra-quebra contra o aumento dos ônibus" (Última Hora). ${ }^{1}$

A expressão "quebra-quebra", utilizada por dois jornais cariocas, remete a um evento que marcou a reação de populares no estado do Rio de Janeiro, em 1959, quando houve o também desavisado aumento das barcas que fazem o transporte de passageiros, e naquela época também de veículos (sobre o acontecimento ver: http://www.labhoi.uff.br/node/1490). Convulsão e batalha nomeiam a situação, de modo a permitir o leitor formar um ponto de vista, diferentemente de baderna, que já pré-julga o evento.

\footnotetext{
${ }^{1}$ Não foi possível recuperar as manchetes dos jornais Tribuna da Imprensa, $\mathrm{O}$ Dia e $\mathbf{O}$ Fluminense. Do material arquivado desses três jornais desde 1987 restaram somente as imagens que foram recortadas e coladas em série.
} 
O Jornal do Brasil foi o que conseguiu sintetizar o conjunto de questões que envolveram o evento, logo na abertura da reportagem na primeira página:

Quatro lojas saqueadas, mais de 100 ônibus depredados -19 incendiados e 43 completamente destruídos - 90 presos, 58 feridos, tiros, bombas de gás lacrimogêneo, estilhaços de vidro em várias ruas do Centro e milhares de pessoas em longas filas, à espera de transporte. Foram estes os primeiros resultados que a cidade colheu da liminar do juiz Ivaldo Corrêa de Souza autorizando aumento de $50 \%$ nas passagens de ônibus. O tumulto começou logo depois de meio-dia, sob a forma de manifestação com centenas de militantes, interrompendo o trânsito para protestar contra o aumento. No meio da tarde começaram as depredações e os incêndios dos ônibus enfileirados na Avenida Rio Branco e que dali se estenderam à Avenida Presidente Antônio Carlos. O comércio fechou, a PM foi reforçada por pelotões de choque e carros blindados e o Exército ocupou a área da Central do Brasil.

Pelo rádio, em mensagens entrecortadas por palavrões, a política disparava ordens para tentar isolar o Centro da cidade. O próprio secretário de polícia civil, Marcos Heusi, entrou nas transmissões pedindo que os policiais restabelecessem a compostura da linguagem. Foi rechaçado por um palavrão e a sugestão que pegasse o boné e tomasse o rumo de casa. Enquanto isso, tocado pelo vento e ajudado pela proximidade dos ônibus, o fogo se espalhava pela Rio Branco. Todos os recursos do Quartel Central dos Bombeiros, despejados na área central então isolada, não foram suficientes para impedir a destruição total de vários ônibus e de uma Brasília. Só por volta das $18 \mathrm{~h}$, quando a PM conseguiu retirar completamente os manifestantes da avenida, a baderna foi encerrada.

Àquela hora, o prefeito Saturnino Braga já havia obtido do Juiz Correa de Souza a suspensão da liminar que autorizou o aumento. Do Sindicato das Empresas de Transporte de Passageiros se conseguiu a promessa de que não voltará à justiça por reajuste. Saturnino esperava desde sexta-feira a decisão do juiz, mas não previu as consequências.

Em nota oficial, o governador Moreira Franco creditou a baderna a grupos organizados que agiram ostensivamente e "em pontos estratégicos da cidade deflagraram ações visando provocar o caos e a obstar a ação policial". Hoje, às 16 horas, está programada para o mesmo local dos tumultos de ontem uma passeata que reúne grupos da CUT, FAMERJ, professores, funcionários públicos e das diretas-já. (Jornal do Brasil, $1^{\circ}$ de julho de 1987, p.1)

A síntese de capa do Jornal do Brasil já apontava para o roteiro do acontecimento que replicou nos demais jornais: a liminar do juiz, a reação da população em forma de protesto, o tumulto, a ação despreparada da polícia, a ocupação da região da Central do Brasil pelo Exército, as diferentes posições das autoridades municipais, estaduais e federais. Os jornais analisados integralmente também apresentaram em comum o passo a passo do desenrolar dos acontecimentos, interpolando a cronometragem dos eventos, com relatos de experiências individuais daqueles que participaram e/ou testemunharam o ocorrido. 
O jornal Última Hora enfatizou a presença de autoridades da sociedade civil e política na defesa dos presos que eram indiscriminadamente transferidos para a delegacia da Polícia Federal, em face das arbitrariedades cometidas pelas polícias civil e militar do estado do Rio de Janeiro ao longo do dia 30 de junho. Na matéria intitulada "Rio Branco foi por três horas campo de batalha" enfatiza-se a ação da polícia e a presença dos representantes da Ordem dos Advogados do Brasil:

A população duplamente apavorada, pois a ação da PM foi uma demonstração inequívoca de despreparo e truculência. [...] No interior de diversos prédios, pessoas em pânico, não sabiam que rumo tomar, pois a ação desordenada dos PMs desaconselhava a sair de eventuais abrigos [...] um ônibus foi incendiado em frente ao edifício Avenida Central. Nova ação e mais pânico, com PMs usando sprays com gás lacrimogêneo e uma máquina de borrifar gás, apelidada de Pimentinha. [...] Vaiados e xingados pela população, que em coro cantava "marcha soldado cabeça de papel", os PMs se irritavam avançando em bloco contra pequenos grupos que se formavam para fugir dos cassetetes. Dezenas de prisões foram feitas sem critério algum, profissionais da imprensa foram ostensivamente provocados e agredidos, com três prisões de jornalistas verificadas e um policial militar sem a identificação bordada no peito deferia golpes de cassetete a quem estivesse por perto [...] O advogado Felipe Amoedo foi enviado por Nilo Batista para saber das ocorrências e em que pé estava a situação dos presos. Quando saiu da delegacia para se dirigir à Polícia Federal, pois alguns já haviam sido levados, Felipe declarou: "Até agora só vi baderna por parte da polícia, não vi nenhum procedimento legal, estão sendo presas pessoas menores de idade. Não vejo por que a Polícia Federal tenha que se envolver nesse caso. A não ser que o Código Penal tenha sido rasgado. E se isso aconteceu, daqui pra frente ninguém vai poder escarrar na rua, que será enquadrado na Lei de Segurança Nacional. (Última Hora, $1^{\circ}$ de julho de 1987, p. 3)

A redundância das informações e o acúmulo de relatos dispersos sobre o acontecimento servem para criar a sua "monstruosidade", na expressão de Nora, pelo sentimento de medo que instaura. Entretanto, as posições em jogo apresentadas nos editorais se prestam tanto para reforçar o caráter monstruoso do evento quanto para apontar caminhos para uma imprensa mais consequente. Das posições em jogo, destaca-se a polarização entre o editorial da Folha de S.Paulo e do Jornal do Brasil, ambos situados na parte central do primeiro caderno, tendo ao lado uma charge: 


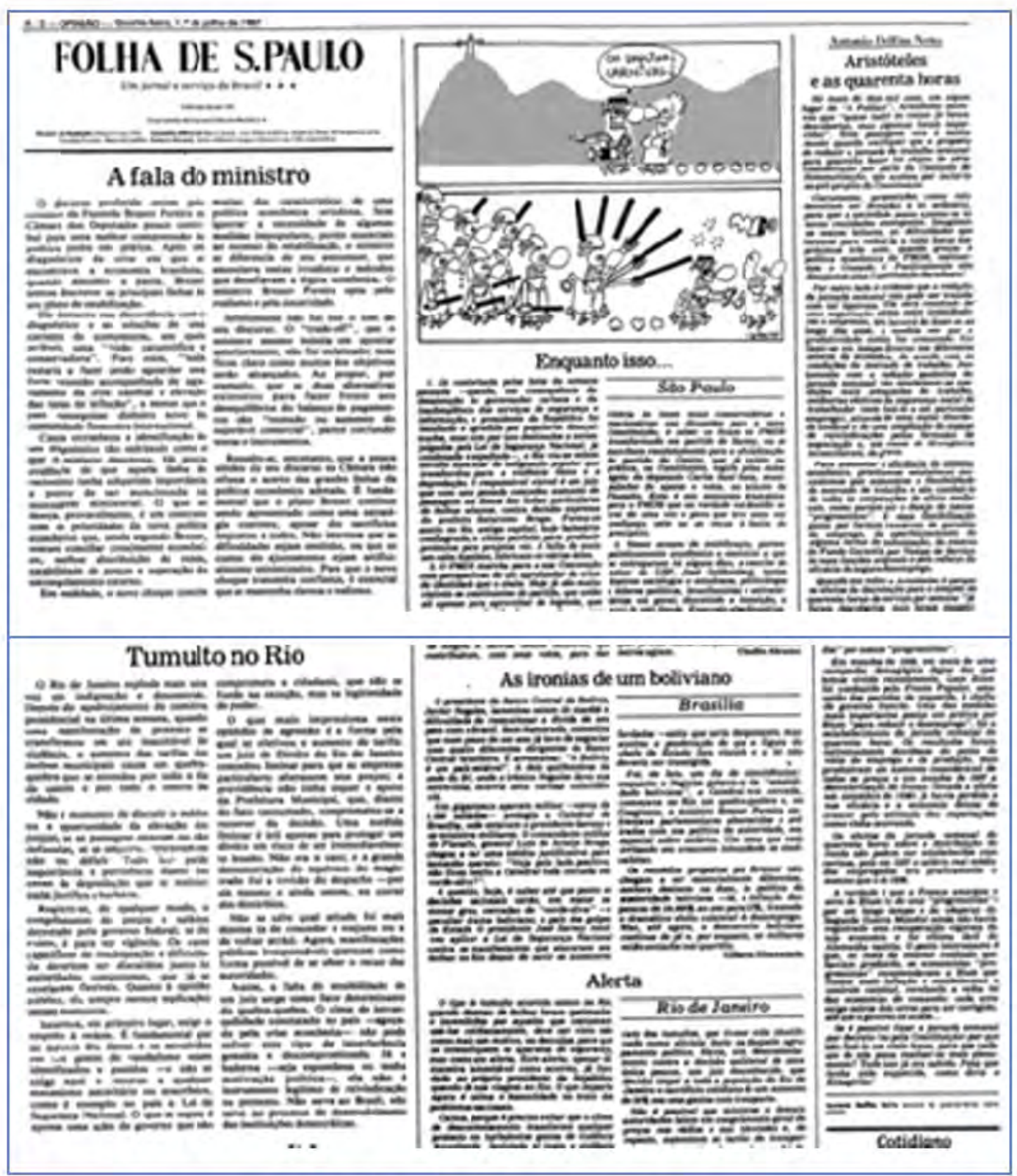

Folha de S.Paulo, $1^{\circ}$ de julho de 1987, p. A2.

Destacam-se no editorial da Folha de S.Paulo os seguintes trechos:

Rio de Janeiro explode mais uma vez em indignação e descontrole [...] o aumento das tarifas de ônibus causa um quebra-quebra [...]. Não é momento de discutir o mérito ou a oportunidade de elevação dos preços [...] tudo isso perde a importância [...] nada justifica a barbárie. Registre-se, de qualquer modo, o congelamento dos preços e salários decretado pelo governo federal; se ele existe, é para ter vigência. [...] Interessa, em primeiro lugar, exigir o respeito à ordem [...] e não se exige aqui o recurso a qualquer mecanismo autoritário ou anacrônico, como é exemplo no país a Lei de Segurança Nacional. $\mathrm{O}$ que se espera é apenas uma ação do governo que 
não comprometa a cidadania, que não se funda na exceção, mas na legitimidade do poder. [...] Assim a falta de sensibilidade de um juiz surge como fator determinante do quebra-quebra. O clima de intranquilidade constatado no país - aguçado pela crise econômica - não pode sofrer esse tipo de interferência gratuita e descompromissada. Já a baderna - seja espontânea ou tenha motivação política -, ela não é instrumento legítimo de reivindicação ou protesto. Não serve ao Brasil; não serve ao processo de desenvolvimento das instituições democráticas. (Folha de S.Paulo, $1^{\circ}$ de julho de 1987, p. A2)

Revela-se na opinião do editorial que a “culpa” pelos eventos do dia 30 de junho é de exclusiva responsabilidade do juiz. Portanto, ao voluntarismo do magistrado a resposta das massas seria a barbárie. Voluntarismo por parte da autoridade e barbárie por parte da população não se inscrevem no registro do Estado de direito e da ordem democrática, e portanto demandam a ação de um Estado forte com tirocínio suficiente para colocar os atores sociais nos seus devidos papéis. As instituições democráticas, no Brasil, segundo o editorial do jornal, não são conquistadas nas disputas no espaço urbano, mas na ação do poder. Combater o "monstro" com as armas necessárias: não é à toa que a charge publicada joga com os desmandos da polícia carioca e com a ocupação das ruas no carnaval.

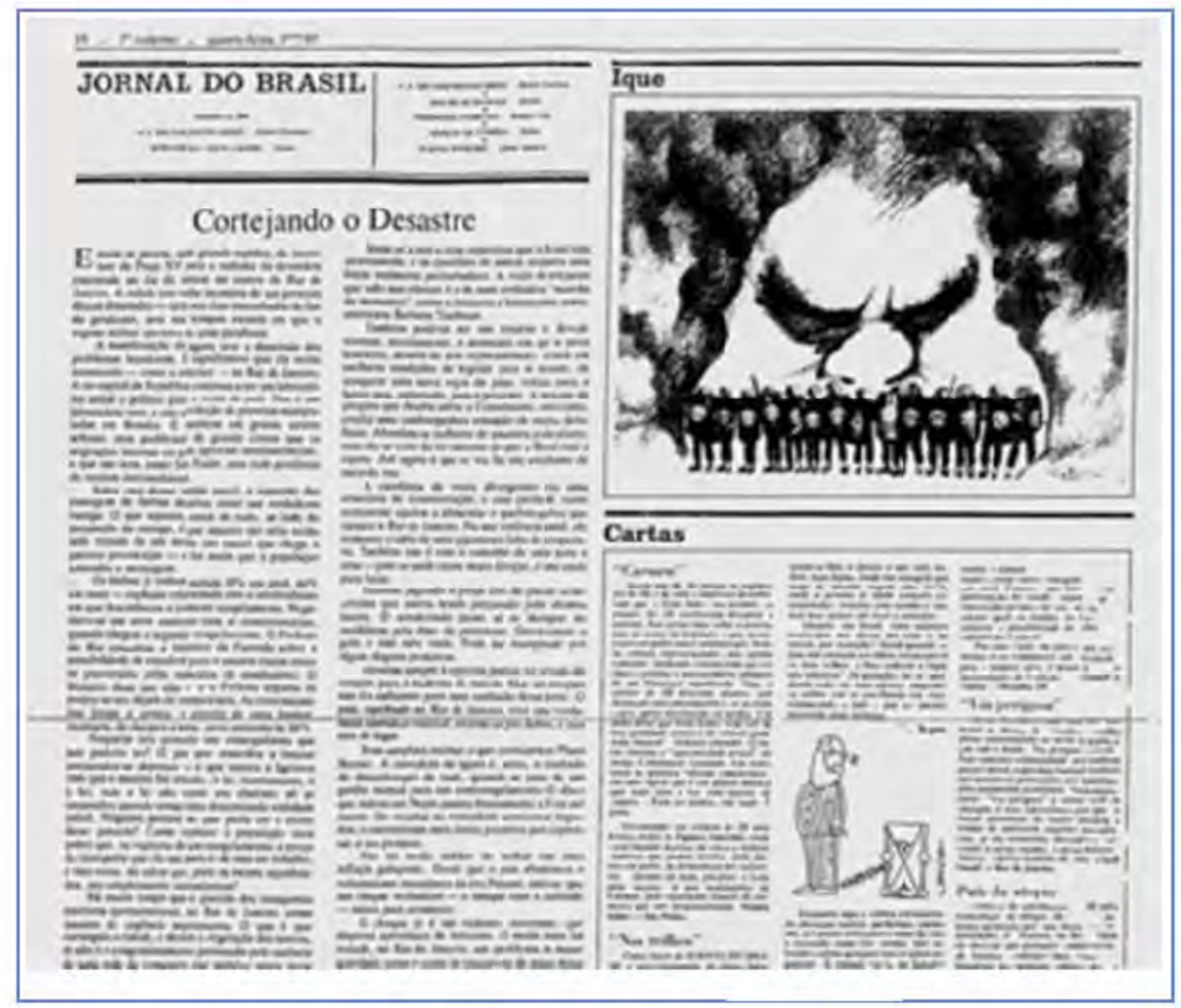

Jornal do Brasil, $1^{\circ}$ de julho de 1987, p. 10. 
No outro lado da argumentação, situa-se o editorial do Jornal do Brasil. O relato se inicia remontando à manifestação de 25 de junho, que resultou no apedrejamento do ônibus em que era transportado o presidente Sarney, no Paço Imperial, no centro da cidade. Denomina a ação de protesto e segue a linha de projetar o acontecimento em perspectiva temporal, na busca de explicações consistentes para o que ocorreu:

A manifestação agora teve a dimensão dos problemas brasileiros. [...] A excapital da República continua a ser um laboratório social e político para o resto do país. Mas é um laboratório vivo, e não uma coleção de provetas manipuladas em Brasília. É também um grande centro urbano, com problemas de grande centro que as migrações internas no país agravam constantemente [...] Sobre esse denso tecido social, o aumento das passagens de ônibus desabou como um verdadeiro castigo. O que espanta é que assunto tão sério tenha sido tratado de modo tão casual que chega a parecer provocação - e foi assim que a população entendeu a mensagem.

Os ônibus já tinham subido $50 \%$ em abril, $44 \%$ em maio - explosão relacionada com 0 artificialismo em que desembocou 0 primeiro congelamento. Negociava-se um novo aumento com as concessionárias, quando chegou o segundo congelamento. O Prefeito do Rio consultou $O$ Ministro da Fazenda sobre a possibilidade de transferir para o usuário custos como os provocados pelo aumento de combustível. O ministro disse que não - e o Prefeito segurou os preços à sua alçada de competência. As concessionárias foram à justiça; e através de uma liminar, instituem, do dia para a noite, novo aumento de $50 \%$.

Ninguém terá pensado nas consequências que isso poderia ter? O juiz que concedeu a liminar arrependeu-se depressa - o que mostra a ligeireza com que $\mathrm{o}$ assunto foi tratado. [...] Como explicar à população mais pobre que, na vigência de um congelamento, o preço do transporte que ela usa para ir de casa ao trabalho e vice-versa, dá saltos que, para os menos aquinhoados, são simplesmente astronômicos? Há muito tempo que a questão dos transportes coletivos apresentava-se, no Rio de Janeiro, como assunto de urgência urgentíssima. O que é que estrangula a cidade, e destrói a vegetação dos morros, se não é o congestionamento provocado pela ausência de uma rede de transporte que viabilize novas áreas de ocupação? Quanto mais pobre, teoricamente mais longe do centro deve morar o cidadão. Mas se ele toma três conduções para chegar ao trabalho, e se esse sistema de transporte não se beneficia de um enfoque 'social', que outra alternativa resta senão a favela ou o viaduto?

Some-se a isto a crise específica que o Brasil está atravessando, e os episódios de ontem assumem uma feição perturbadora. [...] vivemos, teoricamente, o momento em que o povo brasileiro, através de seus representantes, estaria em melhores condições de legislar para si mesmo, de instaurar uma nova regra do jogo, voltada para o futuro, mas sobretudo, para o presente. A torrente de projetos que desaba sobre a constituinte, entretanto, produz uma constrangedora sensação de miopia detalhista. Abordam-se milhares de assuntos particulares; mas não se trata da lei máxima de que o Brasil está à espera. Até agora o que se viu foi um socialismo de meio de rua. 
A cacofonia de vozes divergentes cria uma atmosfera de desorientação; e essa perda de rumo certamente ajudou a alimentar o quebra-quebra que sacudiu o Rio. Na sua violência inútil, ele transmite a ideia de uma gigantesca falta de perspectiva. Também não é este o caminho de saída para a crise pois se saída existe nesta direção, é uma saída para baixo.

[...] Ativistas sempre à espreita podem ter servido de estopim para a baderna de ontem. Mas um estopim não é o suficiente para uma confusão desse porte. O país, espelhado no Rio de Janeiro, teve uma verdadeira convulsão visceral, revirou-se por dentro e não saiu do lugar. Seria simplista atribuir o que aconteceu ao Plano Bresser. [...] O modo como foi tratado, no Rio de Janeiro, um problema da maior gravidade como o custo do transporte de massa deixa exposta a quantidade de amadores que cruzam os trilhos da realidade brasileira. A situação é séria demais para tanto amadorismo. Não são as soluções de força que resolvem; mas o complô dos diletantes pode dar aos adeptos da força o pretexto de que necessitam para agir. (Jornal do Brasil, $1^{\circ}$ de julho de 1987, p. 10)

$\mathrm{Na}$ abordagem do Jornal do Brasil não houve voluntarismo ou barbárie, mas interesses de classe. A queda de braços entre o poder municipal e os representantes das concessionárias de ônibus, arbitrada por um magistrado de primeira instância, acabou por delinear o retrato do Brasil. A charge do cartunista acompanha a lógica do editorial, pois lança para o Planalto Central a responsabilidade pelos acontecimentos no Rio.

O retrato do Brasil que se projeta por meio dos textos da cobertura jornalística encontra uma dimensão alternativa, nem sempre complementar, no registro fotográfico do acontecimento. Já se observou acima que os jornais do Rio de Janeiro realizaram uma cobertura marcadamente visual, quer seja pela proximidade das redações do centro da cidade, onde tudo aconteceu, quer pela afirmação da prática fotográfica, sobretudo o fotojornalismo como forma de expressão nos anos 1980 (MAUAD, 2011).

Nesse momento, o repórter fotográfico, já reconhecido como fotojornalista, havia consolidado por meio das agências independentes um papel político na transição democrática. Paralelamente, por meio da luta sindical, conquistou a valorização do seu trabalho nas redações dos grandes jornais. Portanto, as fotografias que registraram o dia 30 de junho de 1987, mais do que ilustrar as reportagens, projetaram o acontecimento no espaço público visual. 


\section{O acontecimento em cenas}

Entre os depoimentos de vítimas que foram atendidas no Hospital Souza Aguiar, encontra-se o de Carlos Carvalho, então fotógrafo da agência Angular, e o único a fazer a fotografia de Sarney no ônibus com o vidro quebrado, no episódio de 25 de junho de 1987. No depoimento, o fotógrafo, à época com 30 anos, comentou a situação que acompanhava desde a tomada das fotos de Sarney: "De lá pra cá os ânimos estão mais quentes. O pessoal do Planalto não sabe o que está acontecendo na rua... O que vimos agora, apesar da incitação por parte de meia dúzia, foi coisa do povão" (Estado de S.Paulo, $1^{\circ}$ de julho de 1987, p. 9).

A situação do fotógrafo e a sua percepção do desenrolar da situação revela o aprimoramento de uma prática fotográfica participante e engajada, que caracterizaria a sua geração (MAUAD, 2011). No momento em que foi alvejado, Carlos Carvalho estava acompanhado de Marcelo Tarso, fotógrafo do Jornal do Brasil, o que aponta a presença de outros fotojornalistas no cenário dos acontecimentos, à caça de imagens excepcionais que lhe garantiriam uma projeção no campo profissional.

Vale ressaltar que todo o processo de produção de sentido pela fotografia, bem como seu valor autoral, envolve dois movimentos por parte do sujeito-fotógrafo: inscrição e atribuição (LUGON, 2006). Pela dimensão da inscrição se reconhece o investimento por parte do sujeito-fotógrafo em produzir uma imagem que provoque ressonância no campo social no qual desenvolve sua experiência fotográfica. Esse investimento é o resultado de um trabalho social de produção de sentido definida pela relação entre o sujeito e o mundo visível, com apoio dos recursos, técnicas e concepções do meio do qual provém (KRACAUER, 1980). Pelo lado da atribuição se identificam as relações sociais que sustentam a eficácia da imagem fotográfica e estão, diretamente, relacionadas ao regime visual do qual procedem. Assim, uma fotografia adquire valor histórico, tanto pela sua capacidade de responder às demandas visuais do circuito social (produção, circulação, consumo e agenciamento) organizados por diferentes instâncias da cena pública (imprensa, mercado, Estado, movimento social etc.) como pelos recursos técnicos e estéticos utilizados para esse trabalho. 
que se revela em cenas, no sentido de uma história fotográfica.

Em um total de 146 fotografias dos 5 jornais publicados no Rio de Janeiro e 1 em Niterói, avaliaram-se aspectos de nitidez do plano da forma da expressão fotográfica enquadramento, tamanho, sequência - e os itens em destaque no plano da forma do conteúdo fotográfico - fogo, fumaça, polícia, populares, bombeiros, políticos e situações fora do espaço delineado visualmente pelo evento (por exemplo, a foto do juiz que autorizou o aumento na sua casa, ou do casamento que ocorreu no centro da cidade mais tarde em uma igreja).

A análise promoveu as seguintes quantificações:

\begin{tabular}{|c|c|c|c|c|c|c|}
\hline Tamanho & $\begin{array}{l}\text { Jornal do } \\
\text { Brasil }\end{array}$ & O Dia & O Globo & $\begin{array}{l}\text { Tribuna } \\
\text { da } \\
\text { Imprensa }\end{array}$ & $\begin{array}{l}\text { Última } \\
\text { Hora }\end{array}$ & $\begin{array}{c}0 \\
\text { Fluminense }\end{array}$ \\
\hline $\begin{array}{l}\text { Fotos pequenas - } \\
\text { entre } 1 / 8 \text { e } 1 / 16 \mathrm{da} \\
\text { página }\end{array}$ & 1 & 8 & 16 & 13 & 1 & 5 \\
\hline $\begin{array}{l}\text { Fotos médias - 1/4 da } \\
\text { página }\end{array}$ & 9 & 14 & 15 & 8 & 12 & 5 \\
\hline $\begin{array}{l}\text { Fotos grandes }-1 / 2 \text { ou } \\
\text { página inteira }\end{array}$ & 14 & 4 & 5 & 5 & 2 & 13 \\
\hline Total & 26 & 24 & 36 & 26 & 15 & 13 \\
\hline
\end{tabular}

\begin{tabular}{|c|c|c|c|c|c|c|}
\hline Tema da foto & $\begin{array}{c}\text { Jornal do } \\
\text { Brasil }\end{array}$ & O Dia & O Globo & $\begin{array}{c}\text { Tribuna } \\
\text { da } \\
\text { Imprensa }\end{array}$ & $\begin{array}{l}\text { Última } \\
\text { Hora }\end{array}$ & $\begin{array}{c}0 \\
\text { Fluminense }\end{array}$ \\
\hline $\begin{array}{l}\text { Ação policial } \\
\text { Repressão }\end{array}$ & 8 & 8 & 9 & 6 & 7 & 4 \\
\hline $\begin{array}{l}\text { Ação policial } \\
\text { Salvamento }\end{array}$ & 2 & 3 & 2 & 3 & 2 & - \\
\hline $\begin{array}{l}\text { Ação policial } \\
\text { Defesa do patrimônio }\end{array}$ & 1 & 1 & 3 & 2 & 1 & - \\
\hline $\begin{array}{l}\text { Ação popular } \\
\text { Ataque ao } \\
\text { patrimônio }\end{array}$ & 7 & - & 10 & 8 & 6 & 1 \\
\hline
\end{tabular}




\begin{tabular}{|l|c|c|c|c|c|c|}
\hline $\begin{array}{l}\text { Ação popular } \\
\text { Reação à repressão }\end{array}$ & 2 & 3 & 4 & 1 & 4 & 1 \\
\hline $\begin{array}{l}\text { Ação popular } \\
\begin{array}{l}\text { Passeata } \\
\text { manifestação }\end{array}\end{array}$ & 1 & 3 & 2 & 1 & - & 3 \\
\hline Patrimônio destruído & 3 & 5 & 3 & 5 & 3 & 3 \\
\hline
\end{tabular}

\begin{tabular}{|l|c|c|c|c|c|c|}
\hline $\begin{array}{l}\text { Objeto central da } \\
\text { foto }\end{array}$ & $\begin{array}{l}\text { Jornal do } \\
\text { Brasil }\end{array}$ & O Dia & O Globo & $\begin{array}{l}\text { Tribuna } \\
\text { da } \\
\text { Imprensa }\end{array}$ & $\begin{array}{l}\text { Última } \\
\text { Hora }\end{array}$ & $\begin{array}{l}\text { O } \\
\text { Fluminense }\end{array}$ \\
\hline Populares & 6 & 11 & 16 & 11 & 8 & 5 \\
\hline Polícia & 7 & 7 & 9 & 5 & 7 & 5 \\
\hline Ônibus & 7 & 5 & 8 & 1 & 5 & 2 \\
\hline Fumaça & 1 & 3 & 4 & 3 & 2 & 2 \\
\hline Fogo & 1 & 1 & 2 & 3 & 3 & 2 \\
\hline Bombeiros & - & - & 2 & - & 1 & 1 \\
\hline
\end{tabular}

\begin{tabular}{|l|c|c|c|c|c|c|}
\hline $\begin{array}{l}\text { Expressão } \\
\text { fotográfica }\end{array}$ & $\begin{array}{l}\text { Jornal do } \\
\text { Brasil }\end{array}$ & O Dia & O Globo & $\begin{array}{l}\text { Tribuna } \\
\text { da } \\
\text { Imprensa }\end{array}$ & $\begin{array}{l}\text { Última } \\
\text { Hora }\end{array}$ & $\begin{array}{l}\text { O } \\
\text { Fluminense }\end{array}$ \\
\hline $\begin{array}{l}\text { Fotos nítidas } \\
\text { enquadramento } \\
\text { central, contrastes } \\
\text { bem definidos, } \\
\text { profundidade de } \\
\text { campo, objeto central } \\
\text { no foco e distribuição } \\
\text { equilibrada dos } \\
\text { elementos na foto }\end{array}$ & 23 & 15 & 32 & 22 & 20 & 9 \\
\hline Fotos pouco nítidas & 1 & 11 & 4 & 4 & - & 4 \\
\hline Sequências do & 1 & 1 & 3 & 1 & 2 & 1 \\
\hline $\begin{array}{l}\text { Fotos fora do } \\
\text { contexto }\end{array}$ & 1 & - & 1 & - & - & - \\
\hline
\end{tabular}

Ao se considerar a relação entre texto (legendas) e imagem na composição do espaço visual, associada aos resultados das tabelas - "Tema da foto" e "Objeto central”-, observam-se polos de oposição que sustentam a produção de sentido pelo registro fotográfico dos jornais: polícia/populares; ordem/desordem (tumulto, baderna, “badernaço”); garantia da propriedade/destruição da propriedade; unidade/dispersão; gás/fogo. 
A série denominada tipo 1 caracteriza-se pela relação entre legenda e imagem e se inicia pela única foto colorida da cobertura de todos os jornais. Nessa série, a força do comentário ou da descrição da cena orienta a narrativa segundo dois princípios: tensão, quando o comentário se sobrepõe à imagem (fotos 1.2,1.3,1.5,1.6, 1.7, 1.8, 1.11, 1.13, 1.15, 1.16, 1.17); ilustração, quando as imagens amplificam o sentido da legenda (fotos 1.1, $1.4,1.9,1.10,1.12,1.14)$.

Foto 1 (composta pelo primeiro conjunto de imagens tipo 1)

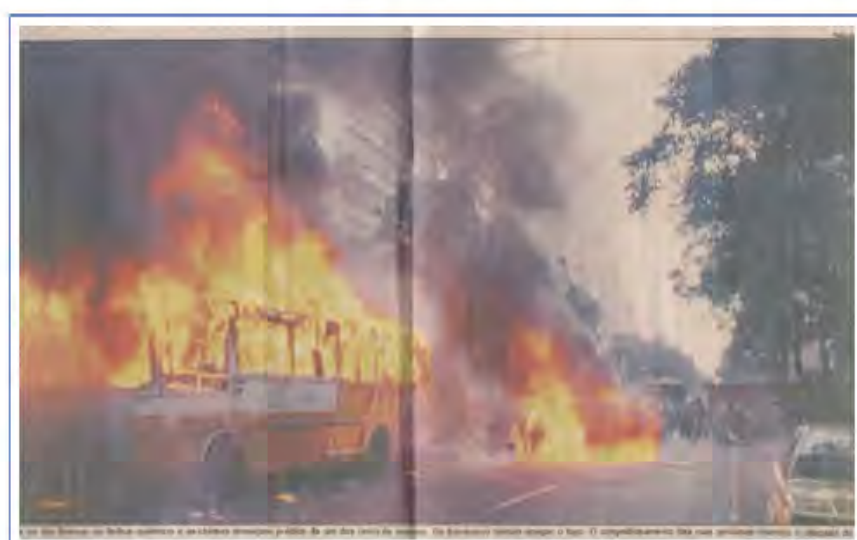

1.1 - "Cena nunca vista na Rio Branco: os ônibus queimam e ameaçam prédios de um dos lados da avenida. Bombeiros tentam apagar o fogo. O congestionamento das ruas próximas retardou a chegada do socorro"(Foto de Aníbal Philot, O Globo, p. 1 única foto colorida de todas as reportagens)

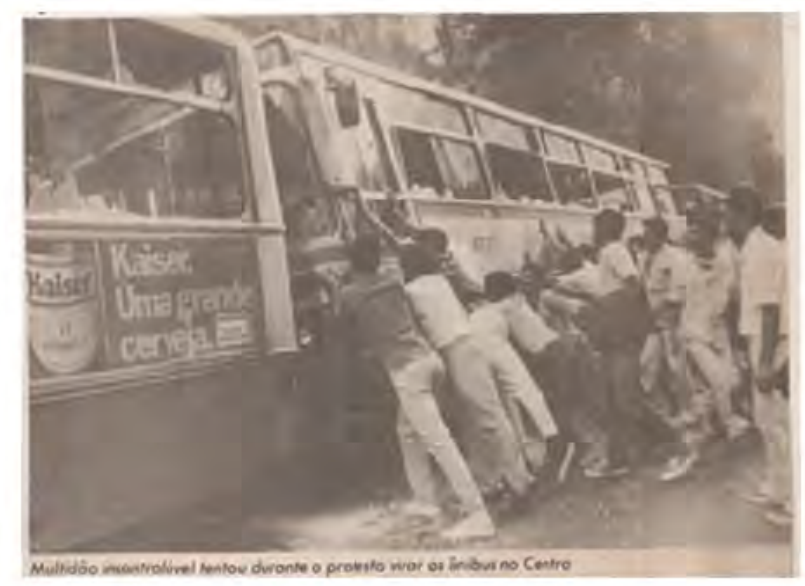

1.3 - "Multidão incontrolável tentou durante o protesto virar os ônibus no Centro", s/i, Última Hora, 1/07/1987

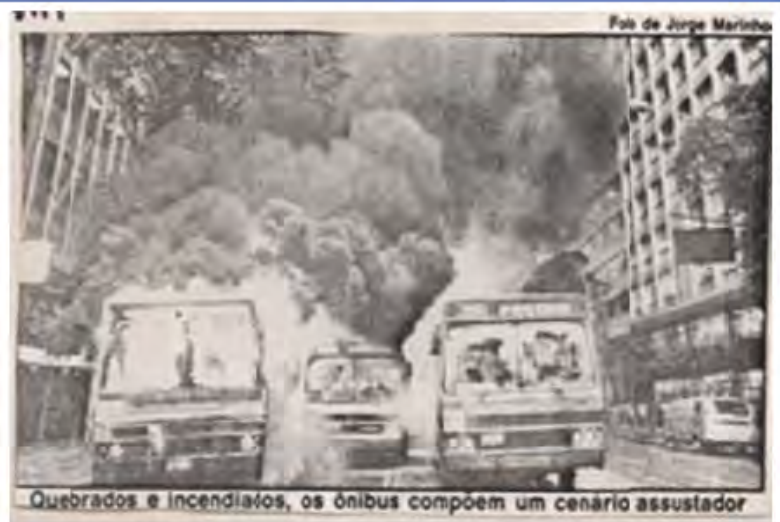

1.2 - "Quebrados e incendiados, os ônibus compõem um cenário assustador”, foto de Jorge Marinho, 0 Globo, 1/07/1987

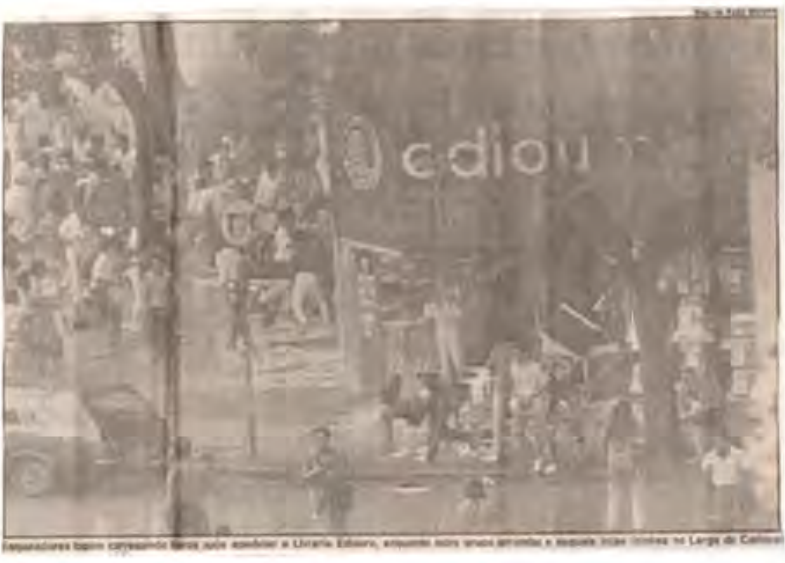

1.4 - "Saqueadores fogem carregando livros após apedrejar a Livraria Ediouro, enquanto outro grupo arromva e saquia lojas vizinhas no Largo da Carioca, Foto de Paulo Moreira, O Globo, 1/07/1987 
Foto 2 (composta pelo segundo conjunto de imagens tipo 1)

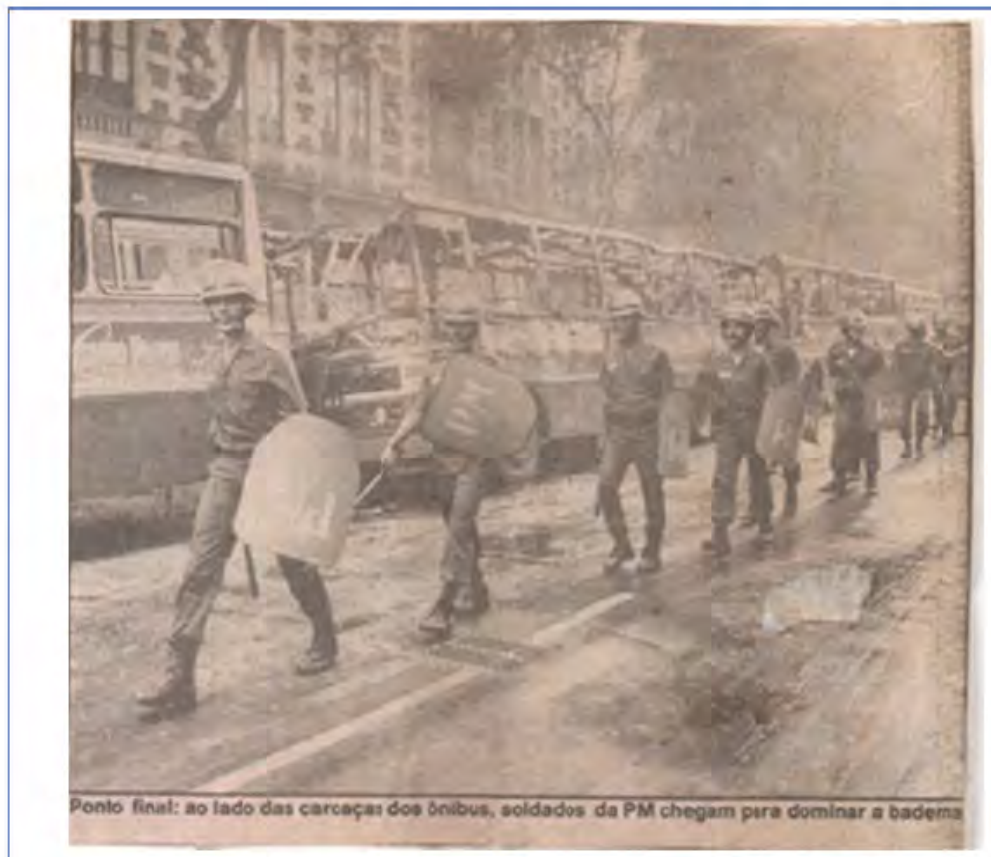

1.5 - "Ponto final: ao lado das carcaças dos ônibus, soldado da PM chegam para dominar a baderna", s/i, O Globo, 1/07/1987

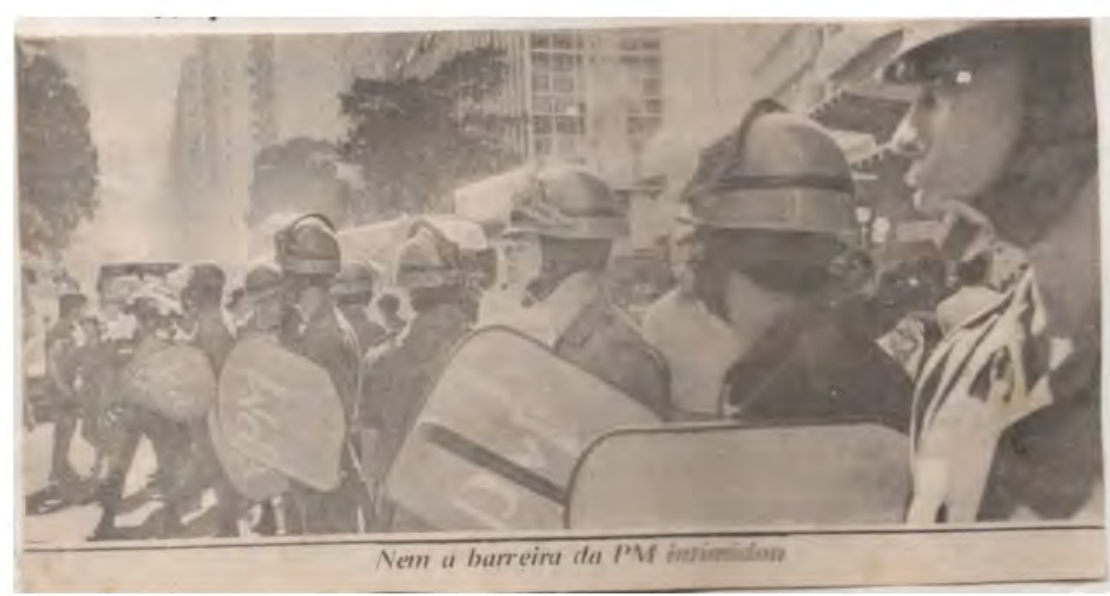

1.7 - “Nem a barreira da PM intimidou”, s/i, Tribuna da Imprensa, 1/07/1987

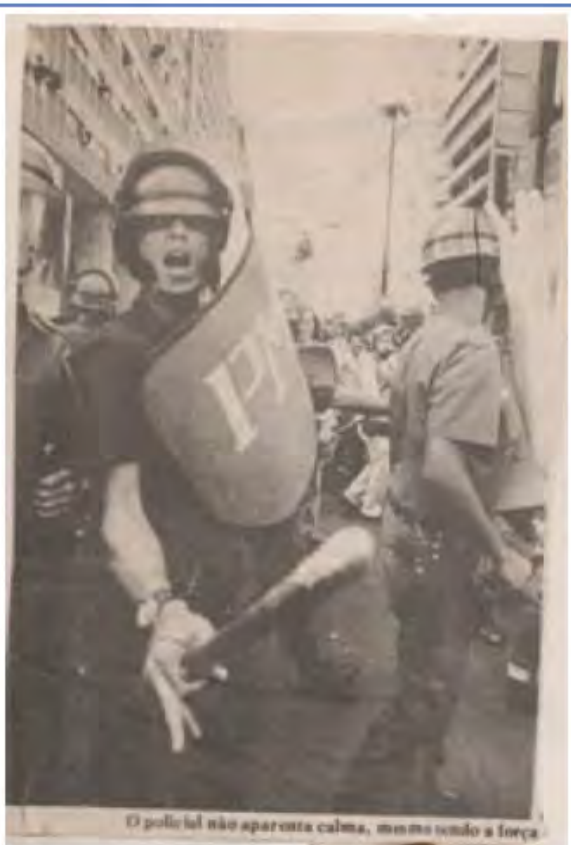

1.6 - "O policial não aparenta calma, mesmo tendo a força, s/i, 0 Fluminense, $1 / 07 / 1987$

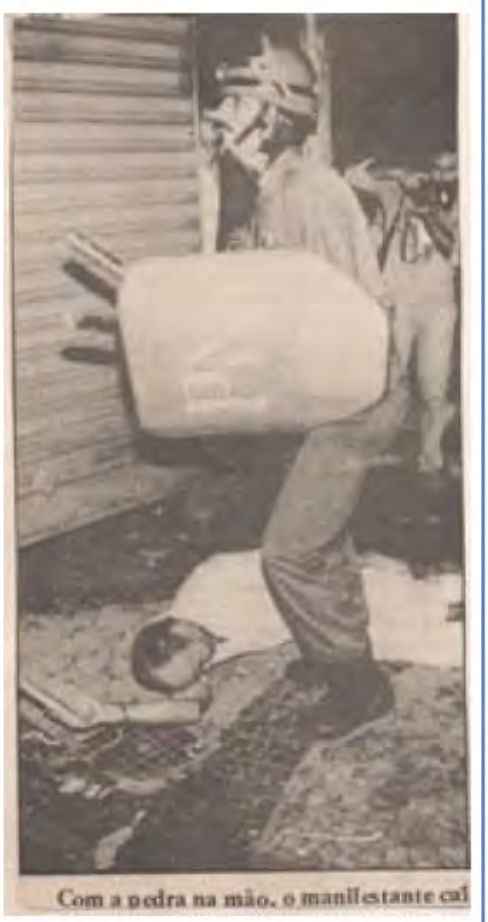

1.8 - “Com a pedra na mão, o manifestante cai", s/i, O Fluminense, 1/07/1987 


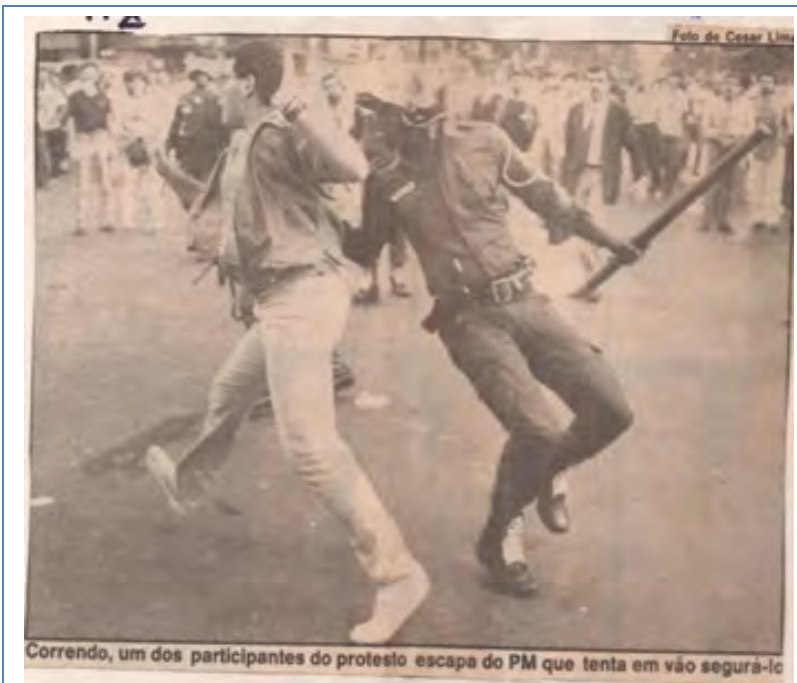

1.9 - "Correndo, um dos participantes do protesto escapa do PM que tenta em vão segurá-lo, foto de Cesar Lima, O Globo, 1/07/1987

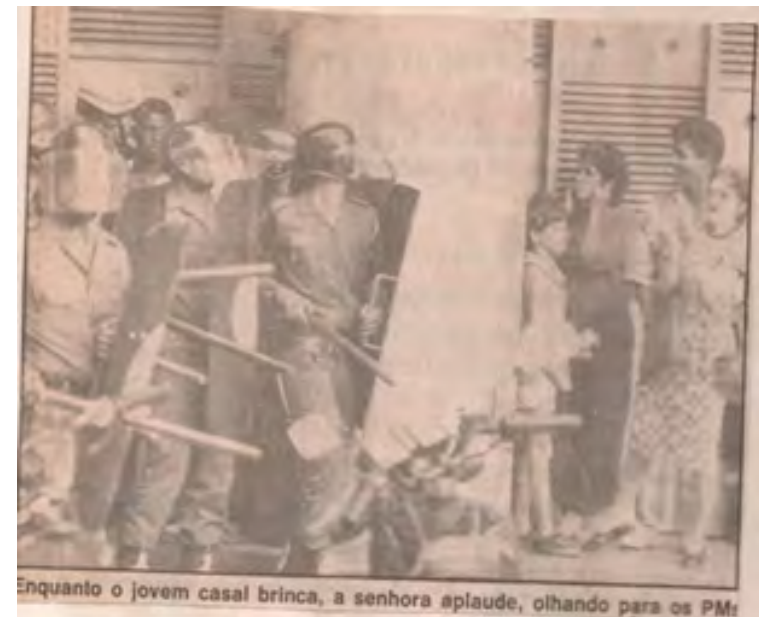

1.11 - "Enquanto jovem casal brinca, a senhora aplaude, olhando para os PMs”, s/i, O Globo, 1/07/1987

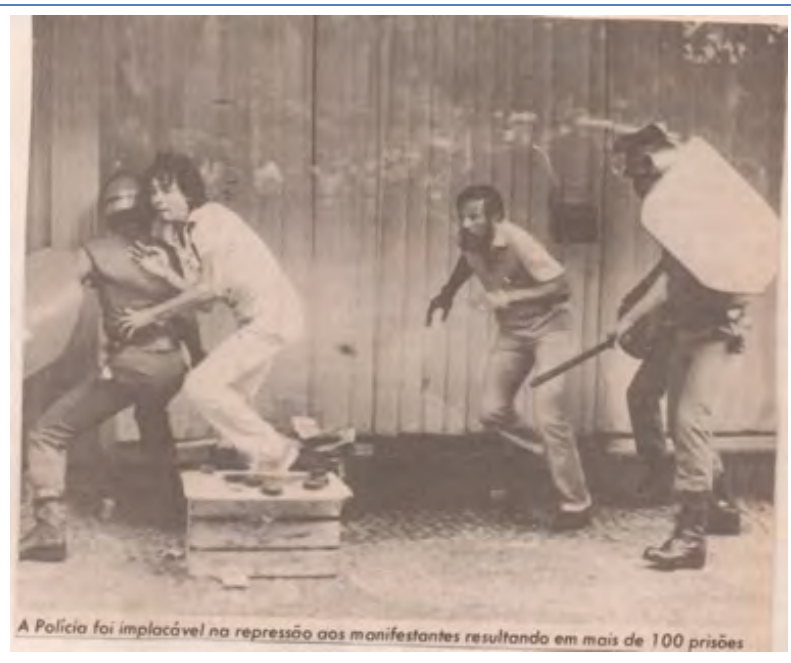

1.10 - "A polícia foi implacável na repressão aos manifestantes resultando em mais de 100 prisões", s/i, Última Hora, 1/07/1987

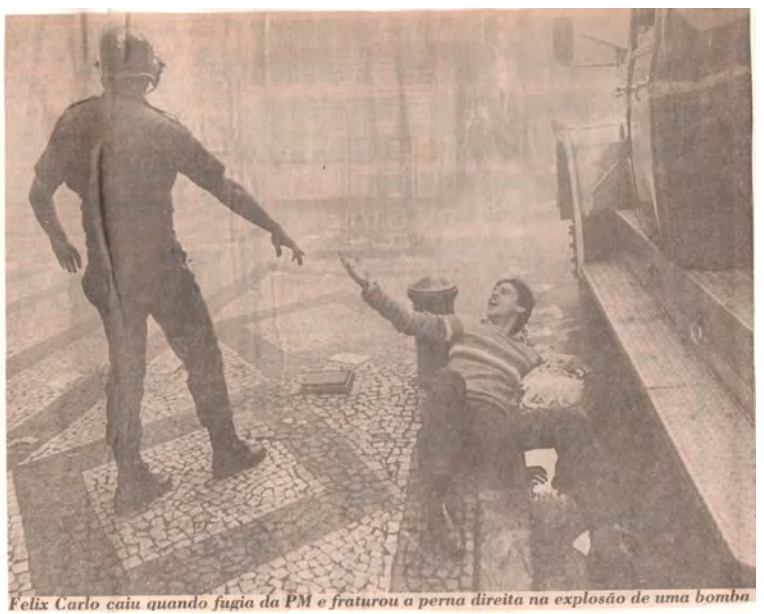

1.12 - "Feliz Carlo caiu quando fugia da PM e fraturou a perna direita na explosão de uma bomba", s/i, Jornal do Brasil, 1/07/1987 
Foto 4 (composta pelo quarto conjunto de imagens tipo 1)

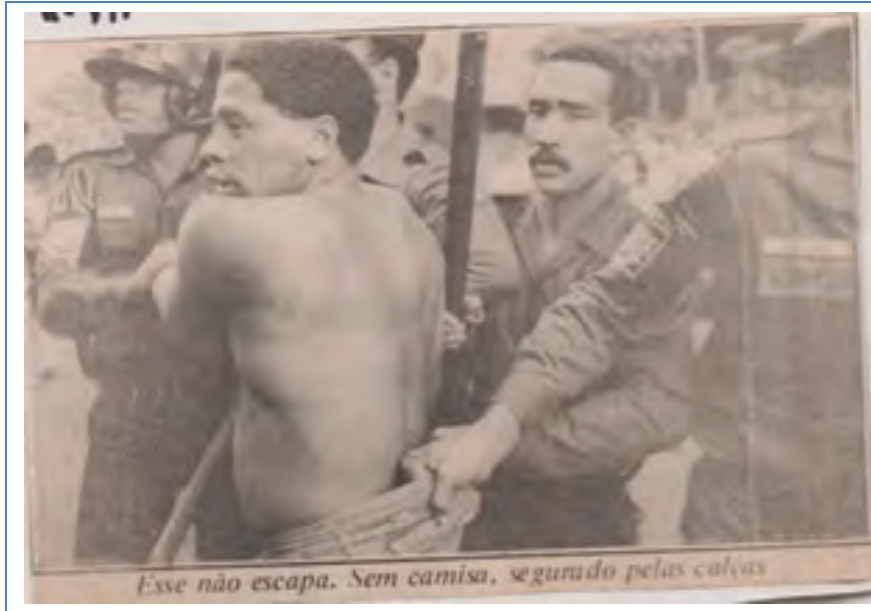

1.13 - "Esse não escapa. Sem camisa, segurando pelas calças", s/i, Tribuna da Imprensa, 1/07/1987

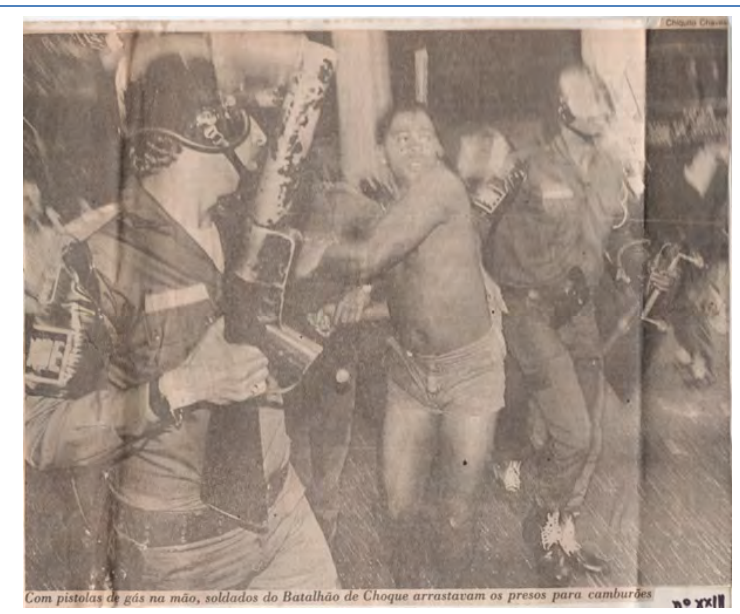

1.14 - "Com pistolas de gás na mão, soldados do Batalhão de Choque arrastavam presos para os camburões, foto de Chiquito Chaves, Jornal do Brasil, $1 / 07 / 1987$

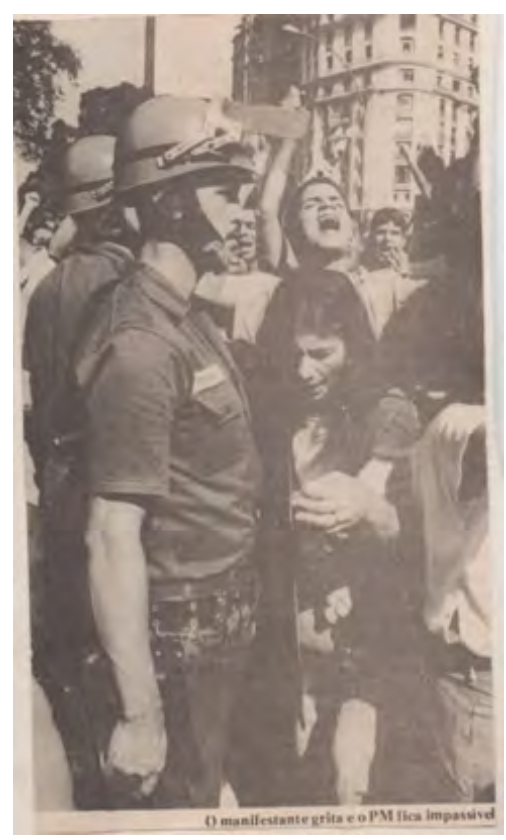

1.15 - "O manifestante grita e o PM fica impassível”, s/i, O Fluminense, $1 / 07 / 1987$

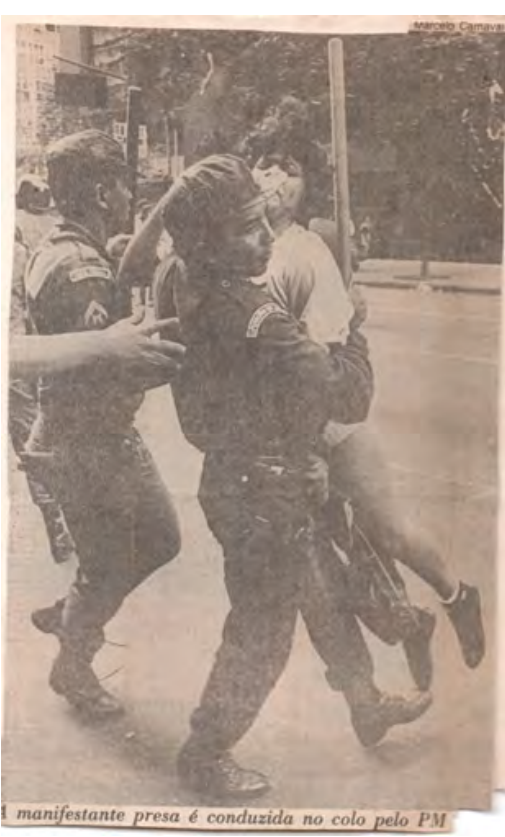

1.16 - "A manifestante presa é conduzida no colo pela PM", foto Marcelo Carnaval, Jornal do Brasil, $1 / 07 / 1987$

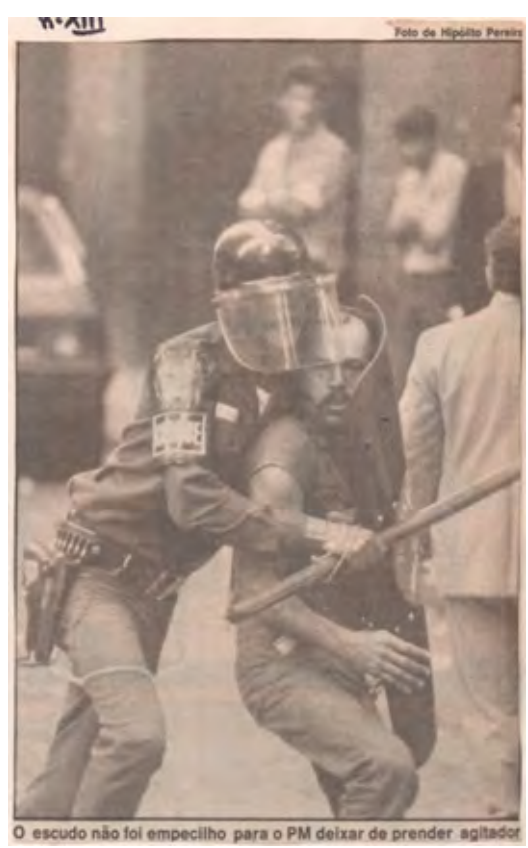

1.17 - "O escudo não foi empecilho para o PM deixar de prender o agitador", foto de Hipólito Pereira, O Globo, 1/07/1987

Do ponto de vista numérico, a distribuição temática entre os jornais acompanha a polarização acima apresentada, pois se distribuem equilibradamente entre a repressão policial e a ação dos populares. Em relação ao protagonismo da cena, o espaço visual foi dividido entre os populares e os policiais, evidenciado na análise dos números das tabelas 
Fotos 5 e 6 - As fotografias que compõem a série tipo 2 foram todas publicadas nos jornais de 01/07/1987.

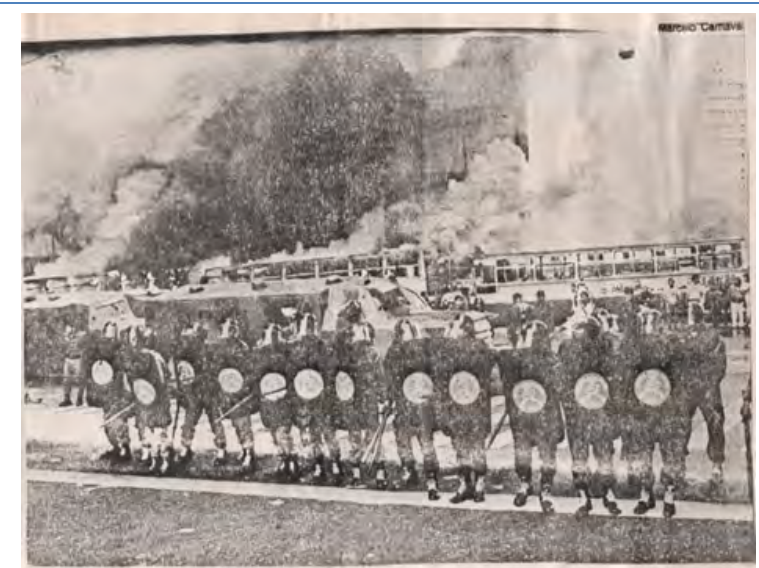

2.1 - Foto de Marcelo Carnaval, JB

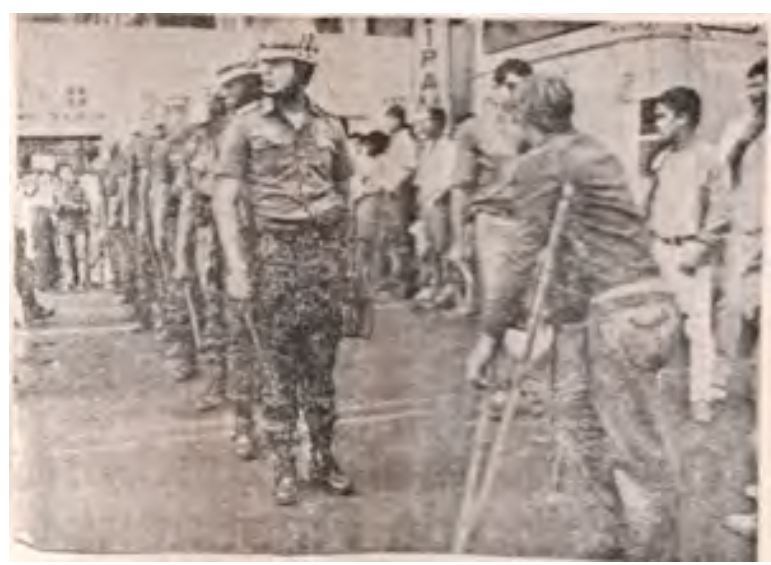

2.3 - O Dia

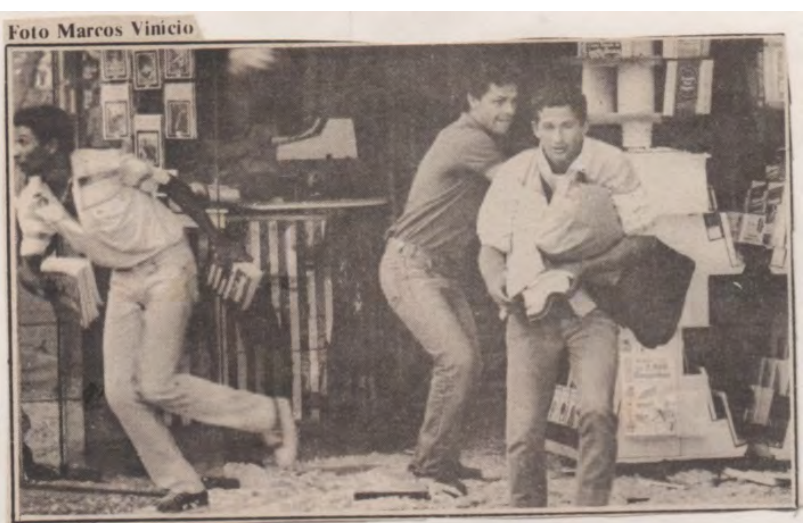

2.5 - Foto de Marcos Venício, Tribuna da Imprensa

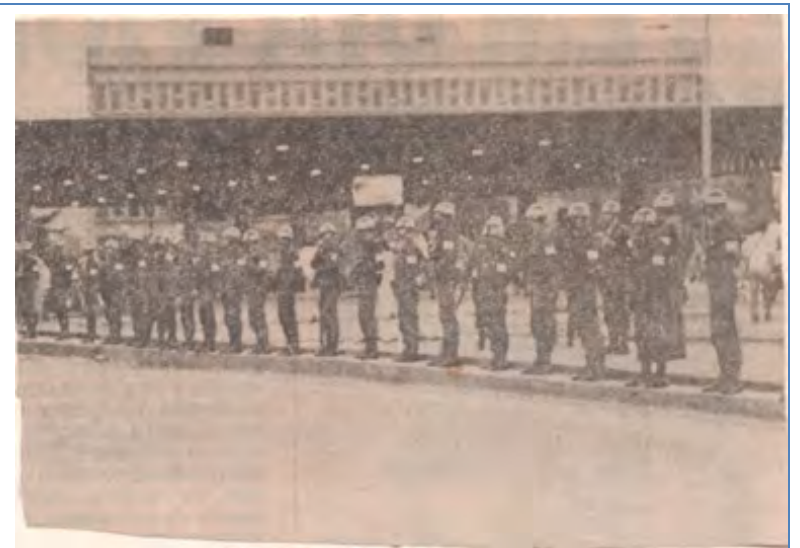

2.2 - O Dia

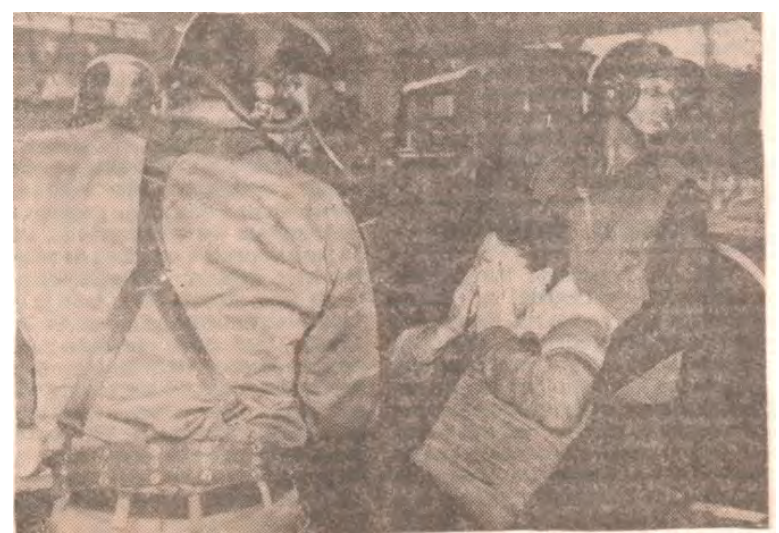

2.4 - O Dia

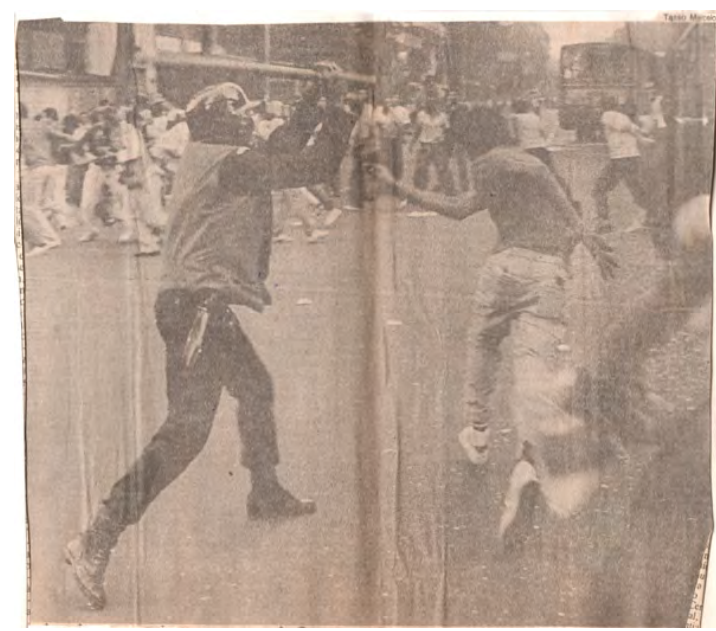

2.6 - Foto de Tarso Marcelo, JB 


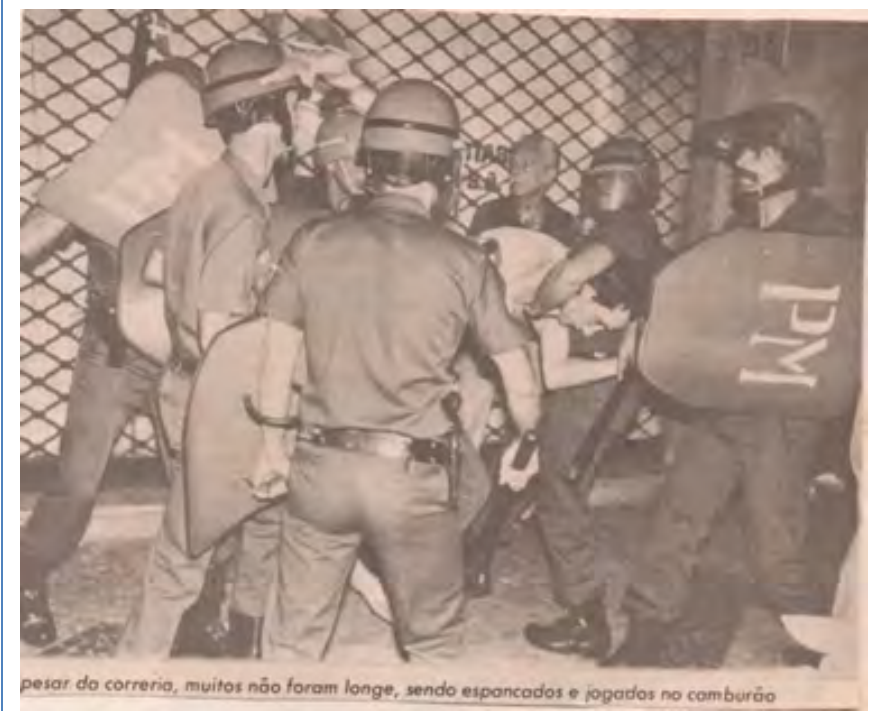

2.7 - Última Hora

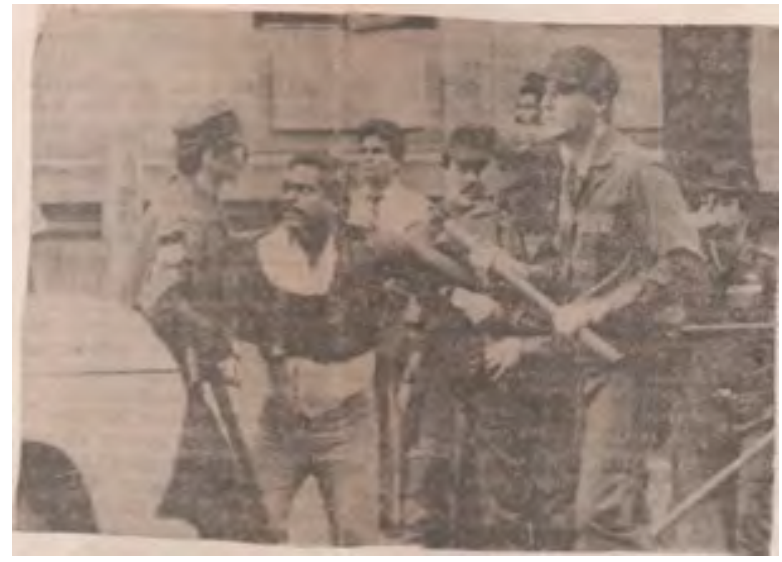

2.9- O Dia

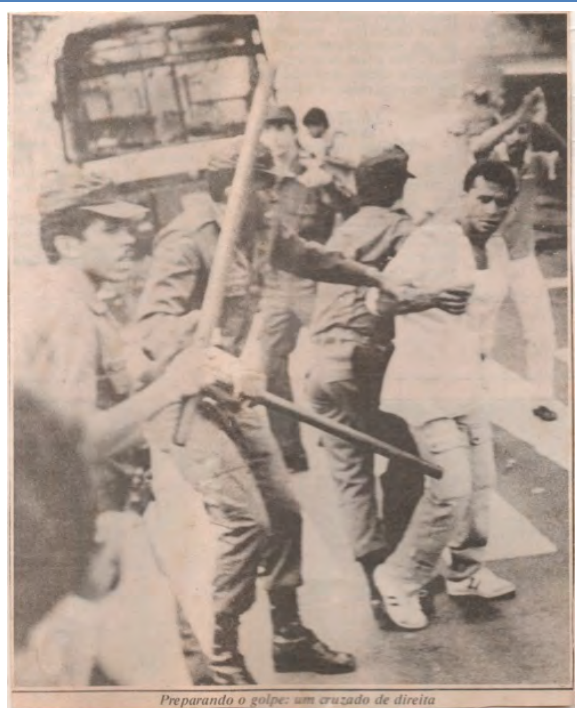

2.8 - Tribuna da Imprensa

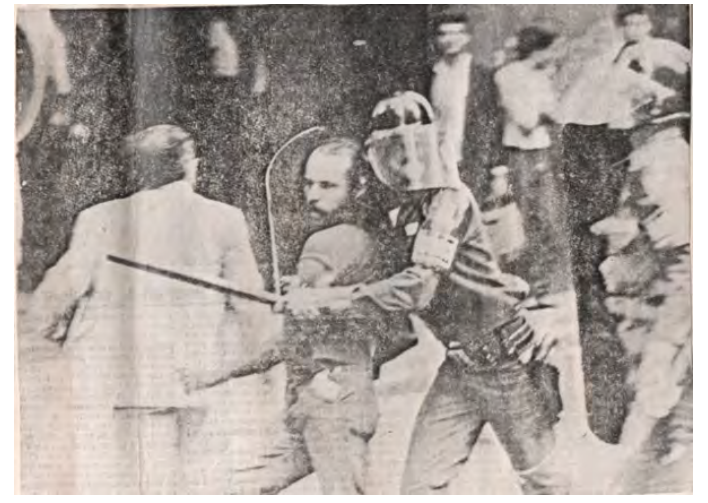

2.10 - O Dia

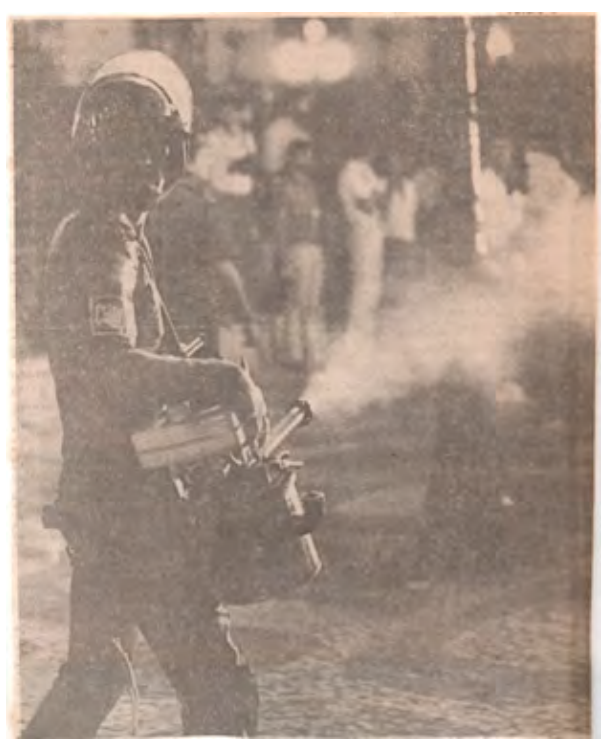

$2.11-J B$ 
Em termos de expressão fotográfica, o predomínio de imagens nítidas, que permitem a observação clara da informação veiculada, associadas a médias e grandes, caracteriza um espaço visual que prioriza a identificação da situação, dos agentes e de sua ação plenamente contextualizados. A série tipo 3 foi dividida em categorias dos agentes que compuseram a performance do acontecimento: fotógrafos (fotos 3.1 e 3.2), vítimas (fotos 3.3, 3.4 3.5, 3.6, 3.7 e 3.8), ação (foto 3.9), reação - bombeiros (3.10) e mais reação - policiais $(3.11,3.12,3.13,3.14$ e 3.15), para evidenciar o peso das imagens de repressão no arranjo visual do acontecimento.

Foto 7, Foto 8 e Foto 9 - As fotografias que compõem a série tipo 3 foram todas publicadas nos jornais de 01/07/1987.

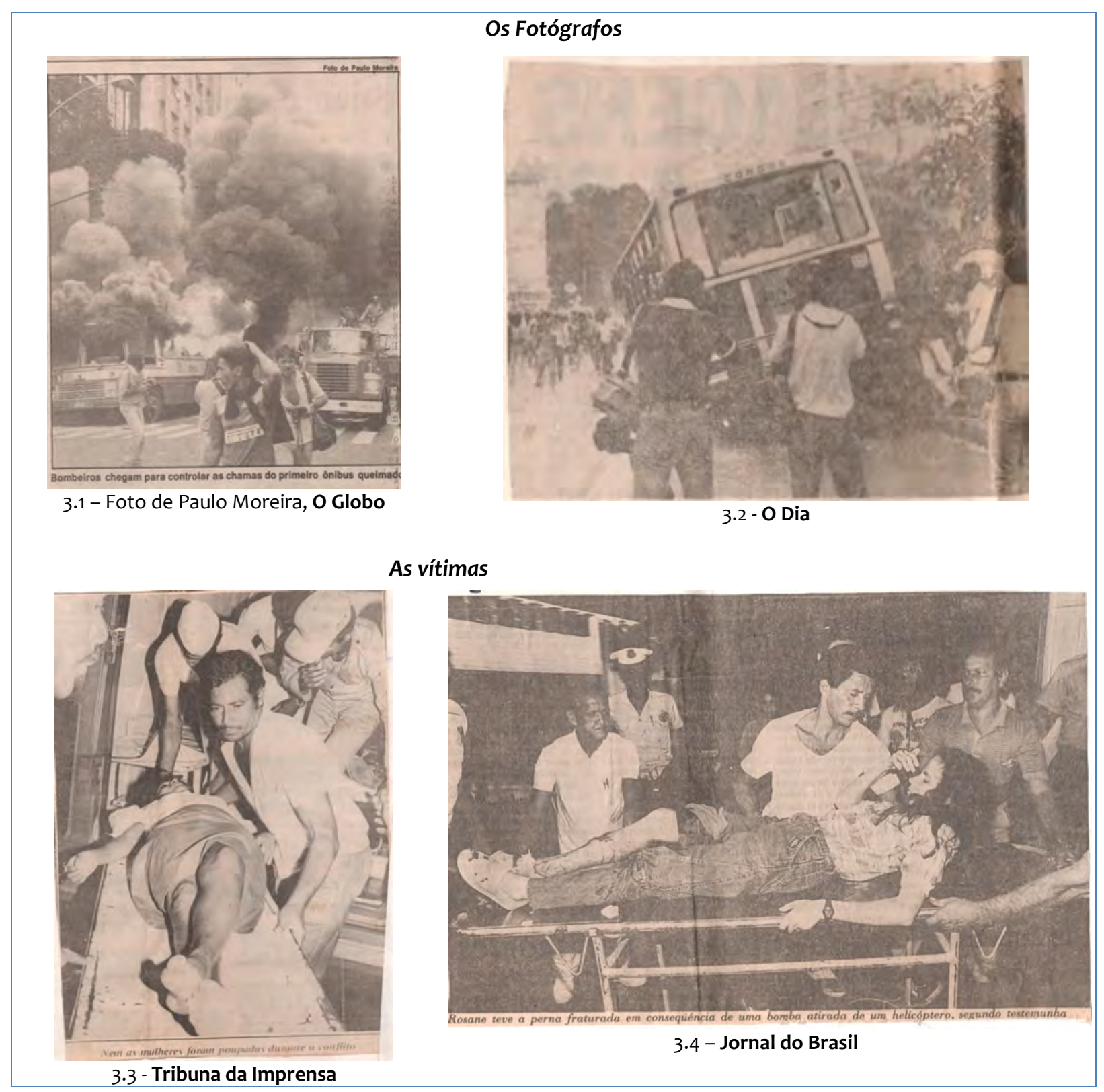




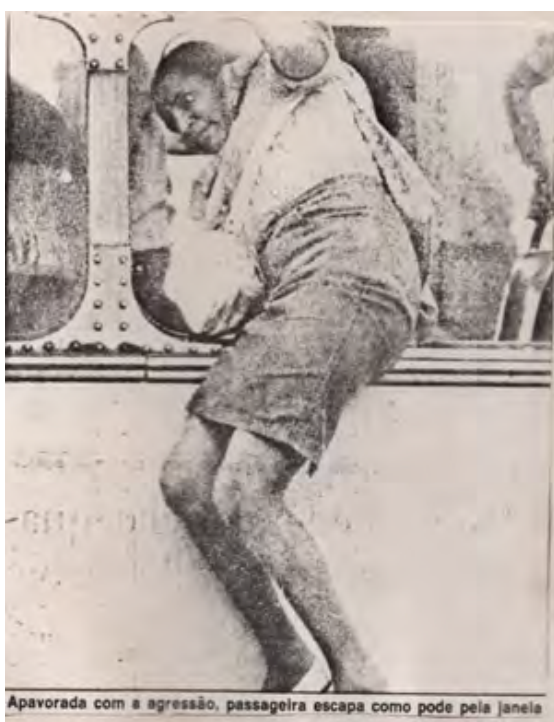

3.5 -O Globo

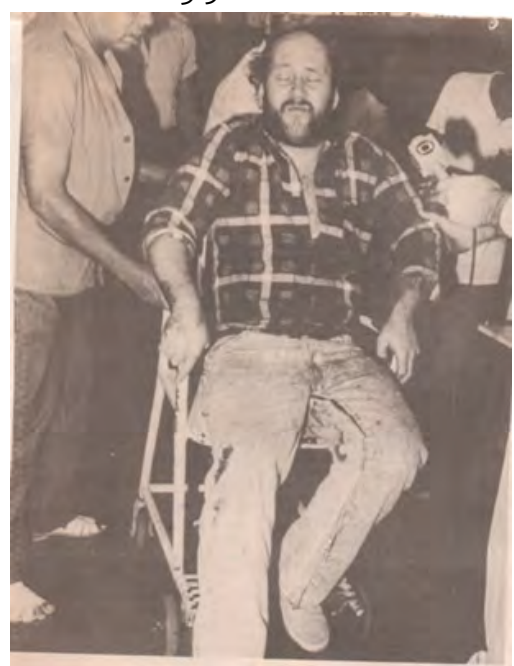

3.7 - Última Hora

Ação

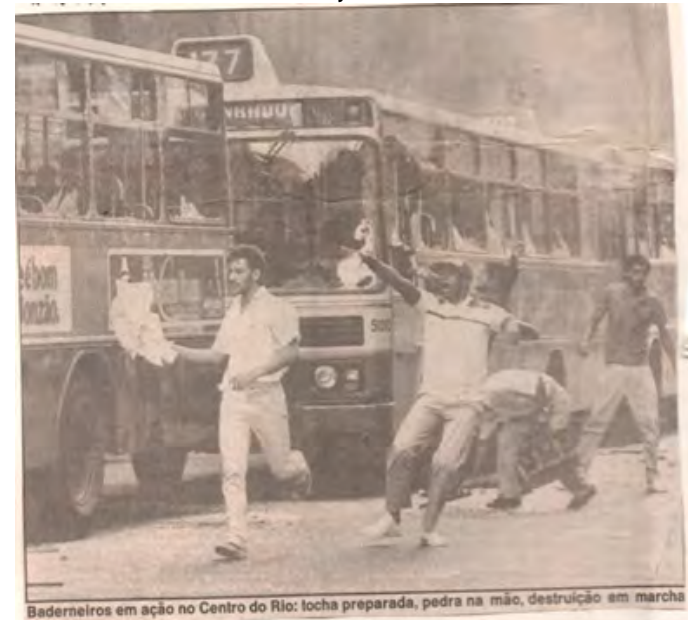

3.9 - O Globo

\section{As vítimas}
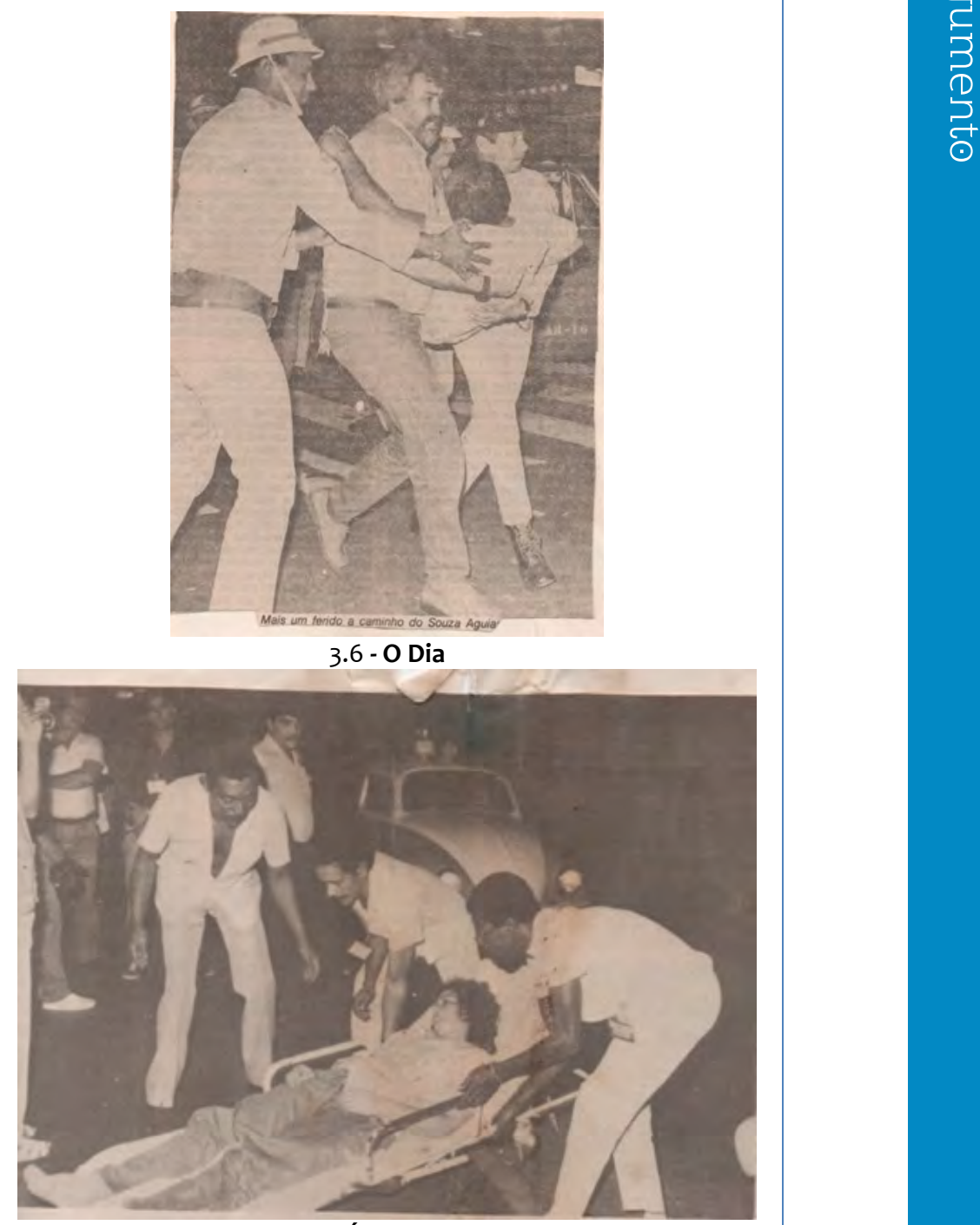

3.8 - Última Hora

Reação

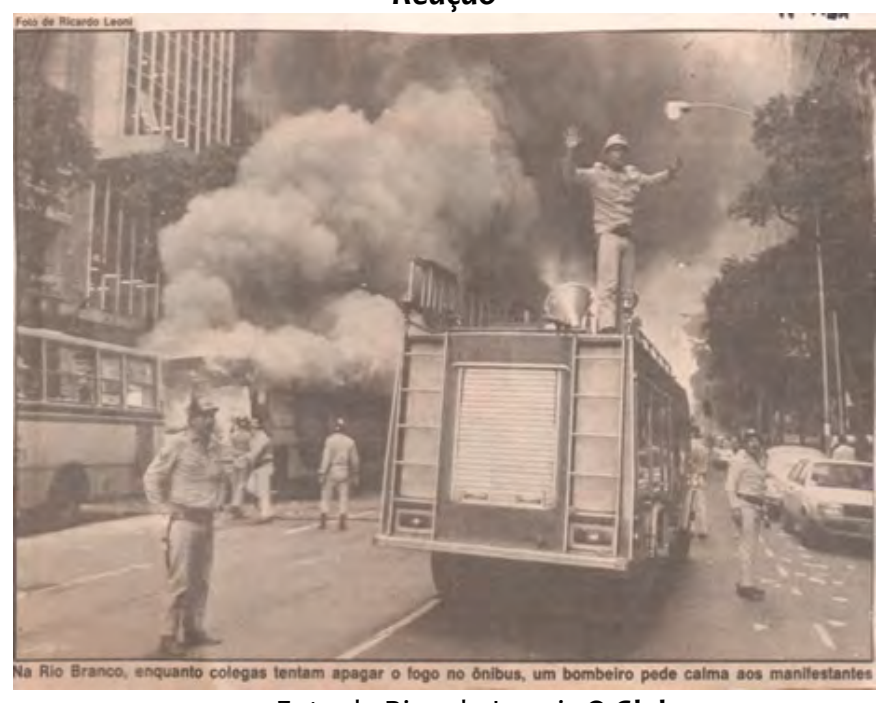

3.10 - Foto de Ricardo Leoni, O Globo 


\section{Mais reação}

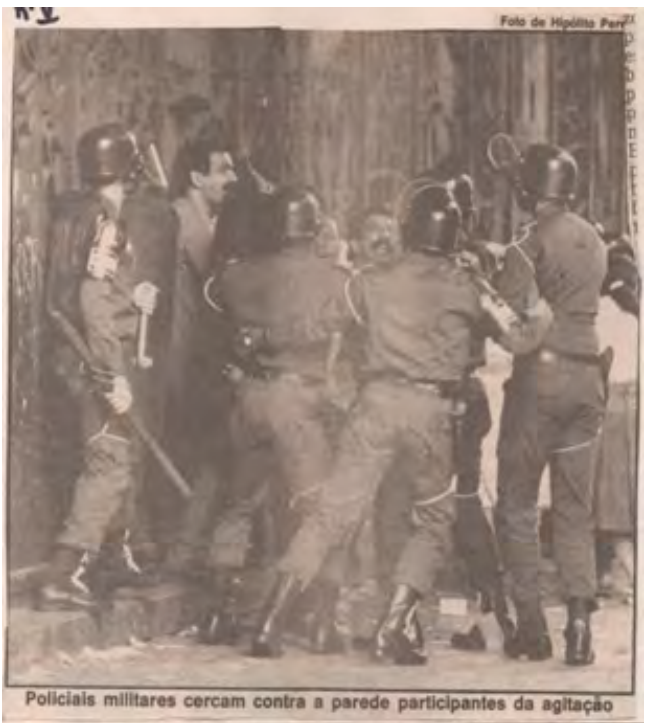

3.11 - O Globo

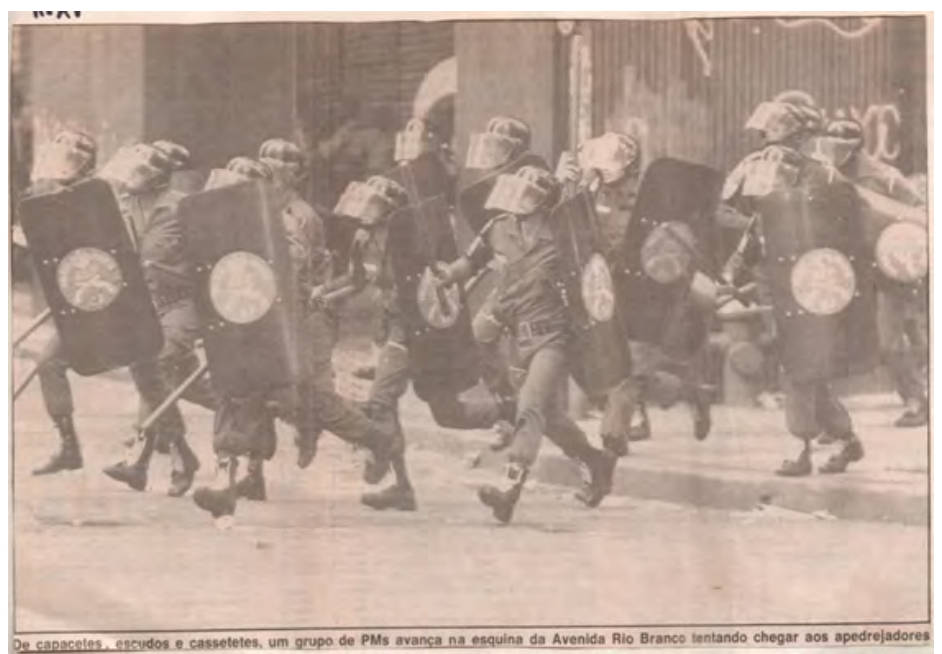

3.13 - O Globo
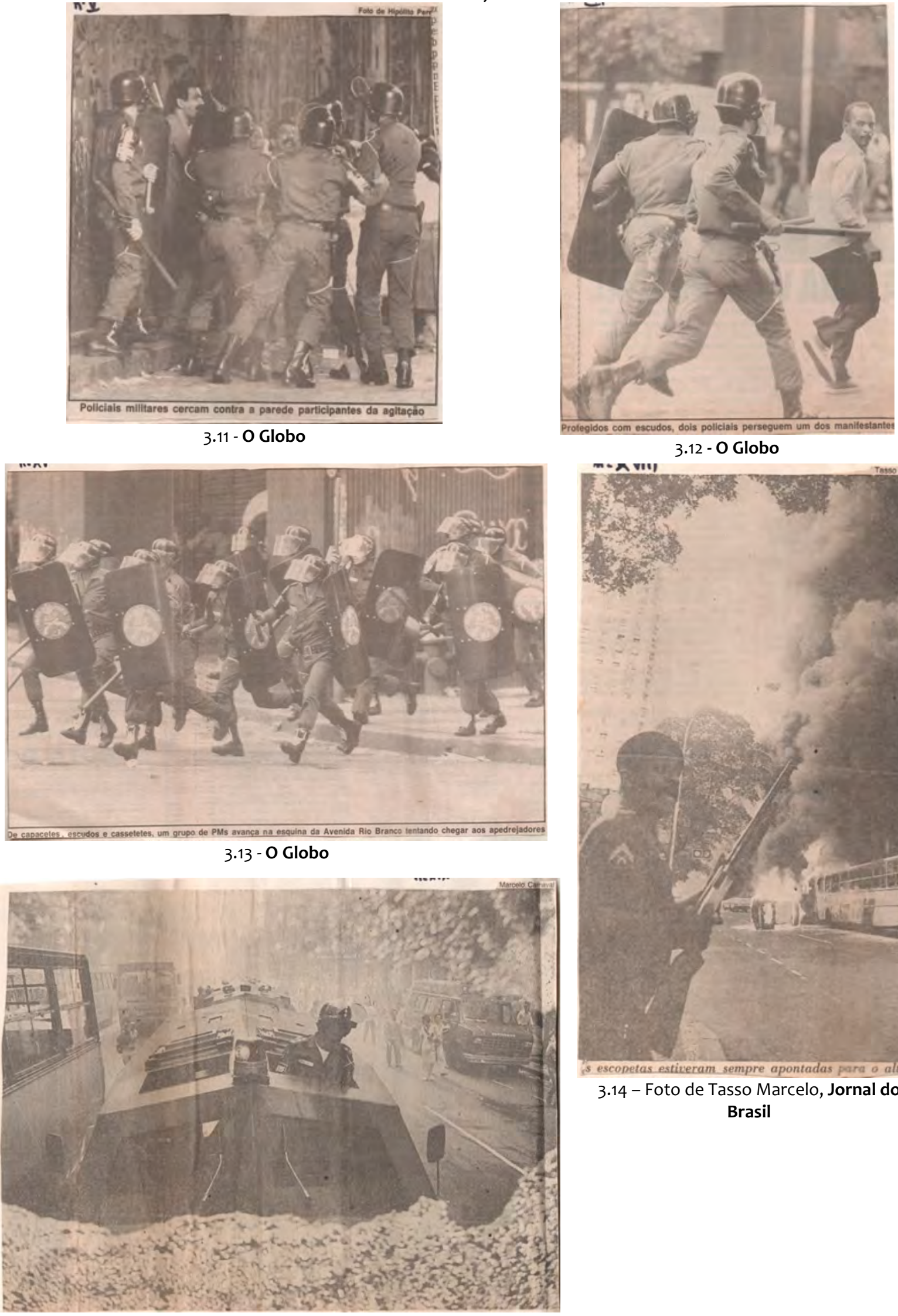

$$
3.12 \text { - O Globo }
$$

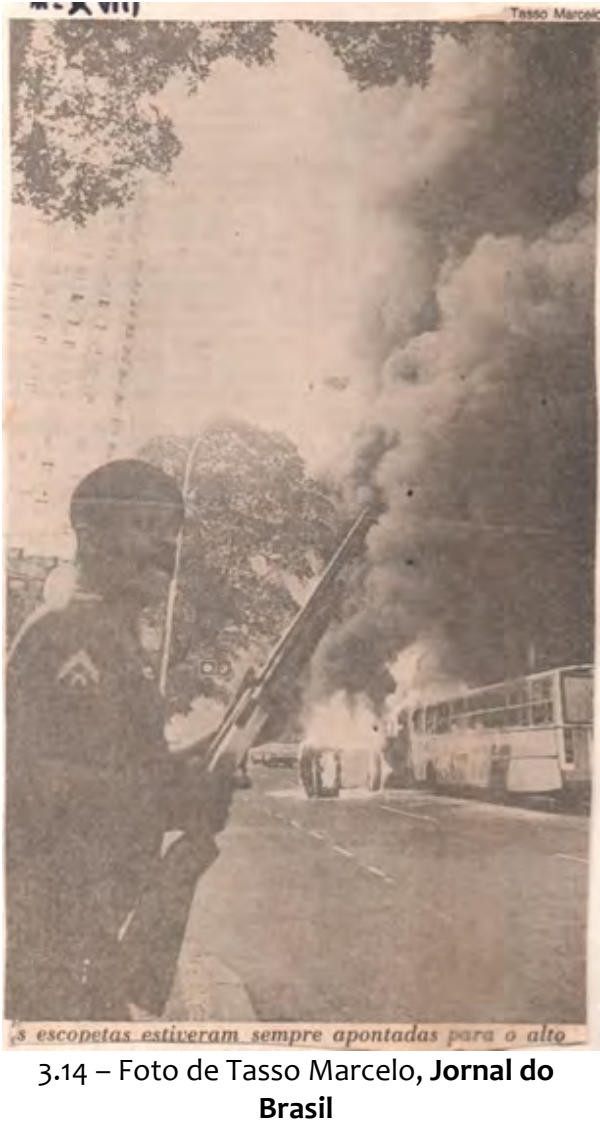

3.15 - Foto de Marcelo Carnaval, Jornal do Brasil 
Algumas características não quantificadas merecem ser registradas, entre elas o arranjo editorial nas páginas. Uma modalidade de arranjo reuniu fotos de diferentes tomadas em uma sequência que compõe uma página gráfica, que se diferencia daquela produzida por uma mesma tomada. No primeiro caso, a narrativa é composta posteriormente, com o objetivo de atribuir sentido aos registros fotográficos segundo a linha adotada pela editoria fotográfica. Já no segundo caso, a observação participativa do fotógrafo anima cenas em planos-sequência, compondo uma versão cinematográfica do acontecimento.

As duas páginas do Caderno Cidade, do Jornal do Brasil, publicado no dia 01/07/1987, caracterizam os dois tipos de arranjo. Na página à esquerda, no plano inferior, a sequência produzida por uma mesma tomada acompanha o ato do manifestante contra o ônibus; enquanto na página seguinte, o arranjo de fotografias tomadas em situações distintas transcreve a ação policial no palco dos acontecimentos. Esses dois tipos de arranjo também foram encontrados nos demais jornais.

Foto 10 - "Caderno Cidade", Jornal do Brasil, 01/07/1987,

http://www.jb.com.br/paginas/news-archive/, acesso em 22 de janeiro de 2016.

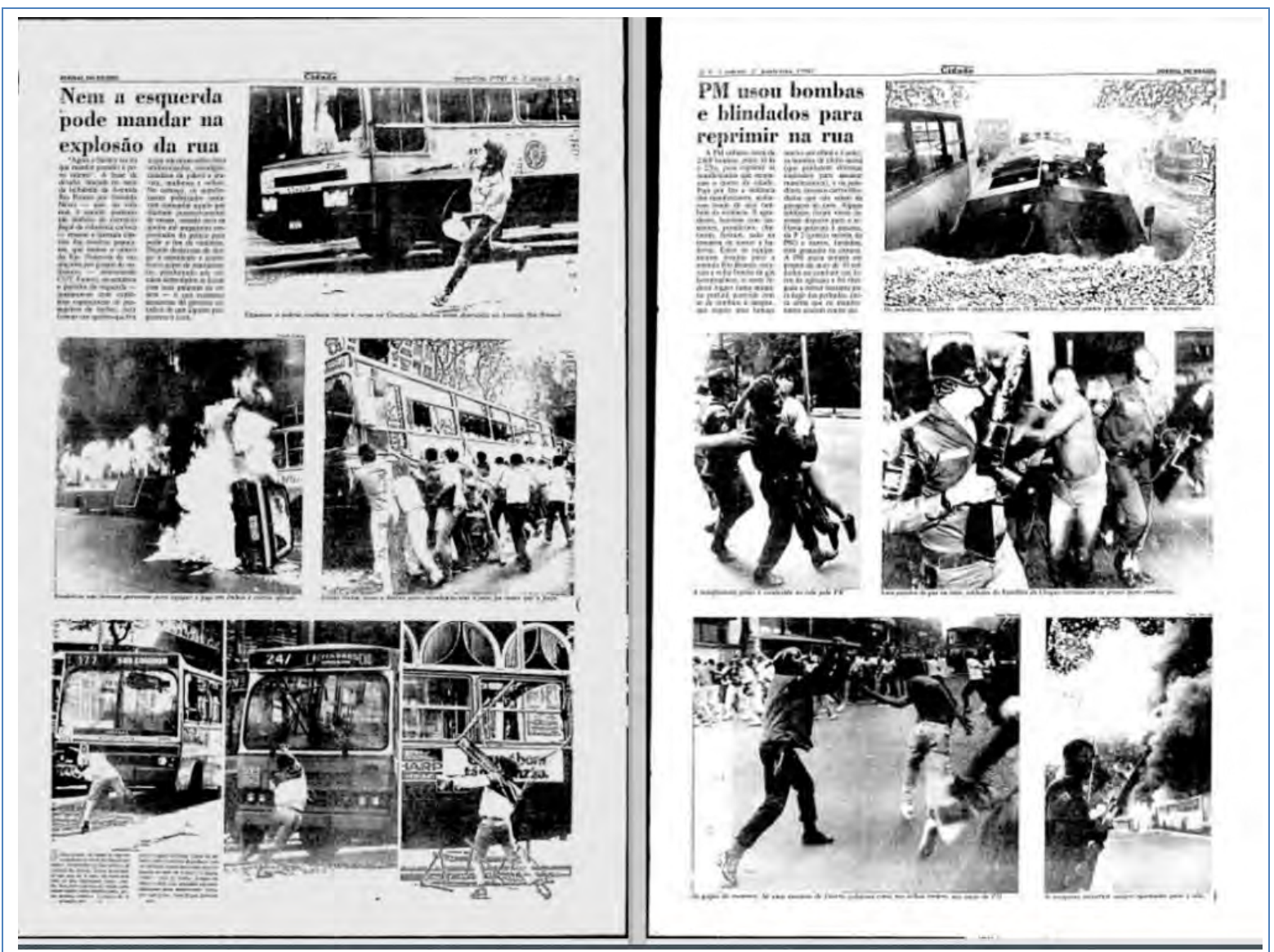


Foto 11 - Arranjo fotográfico que acompanha a reportagem completa do acontecimento, com depoimentos de populares e autoridades, última Hora, 01/07/1987, p. 6.

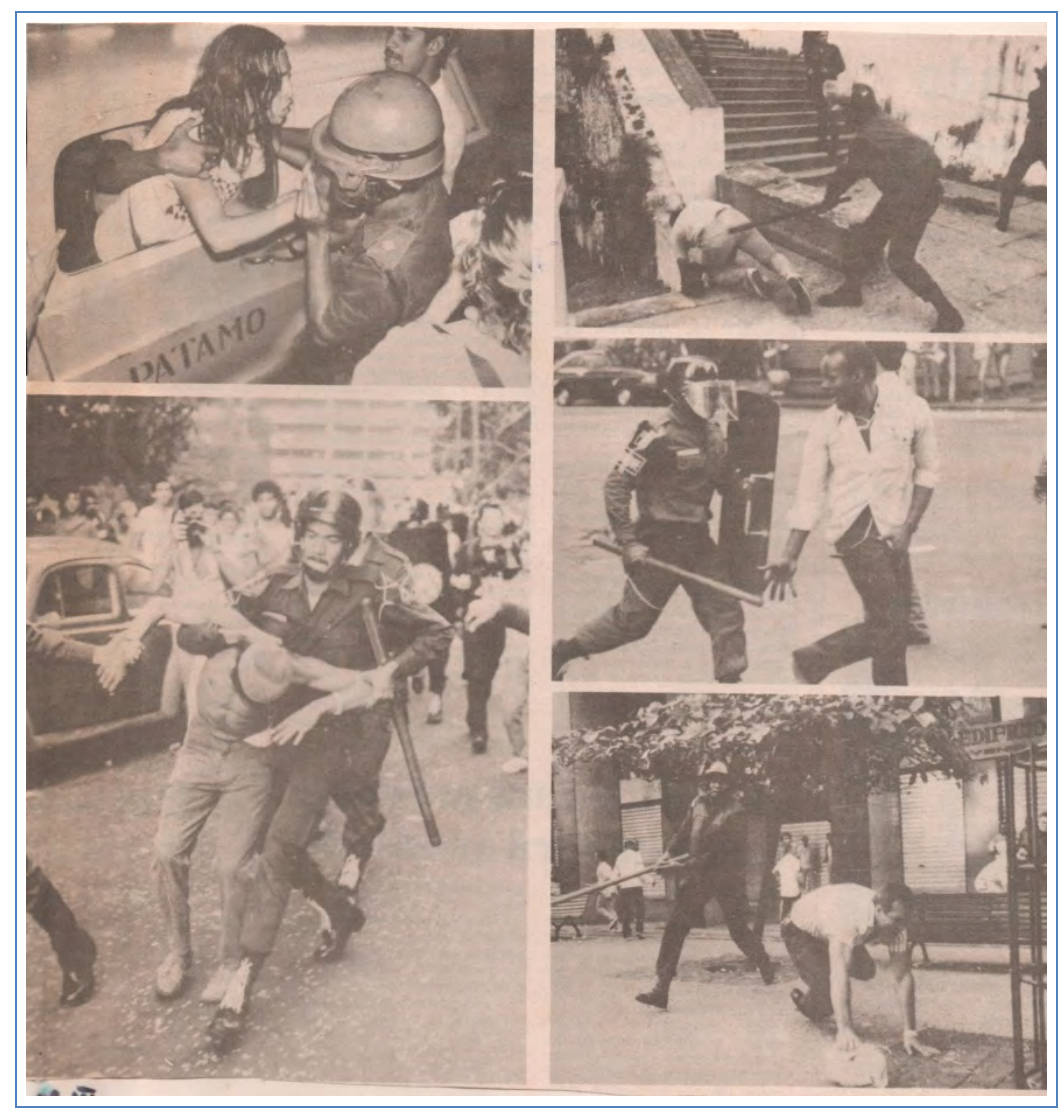

Foto 12 - "Sequência fotográfica Alcyr Cavalcanti", Tribuna da Imprensa, 01/07/1987, p. 6 (publicada na ordem da esquerda para a direita, de cima para baixo, numeradas na sequência, com legendas omentadas).

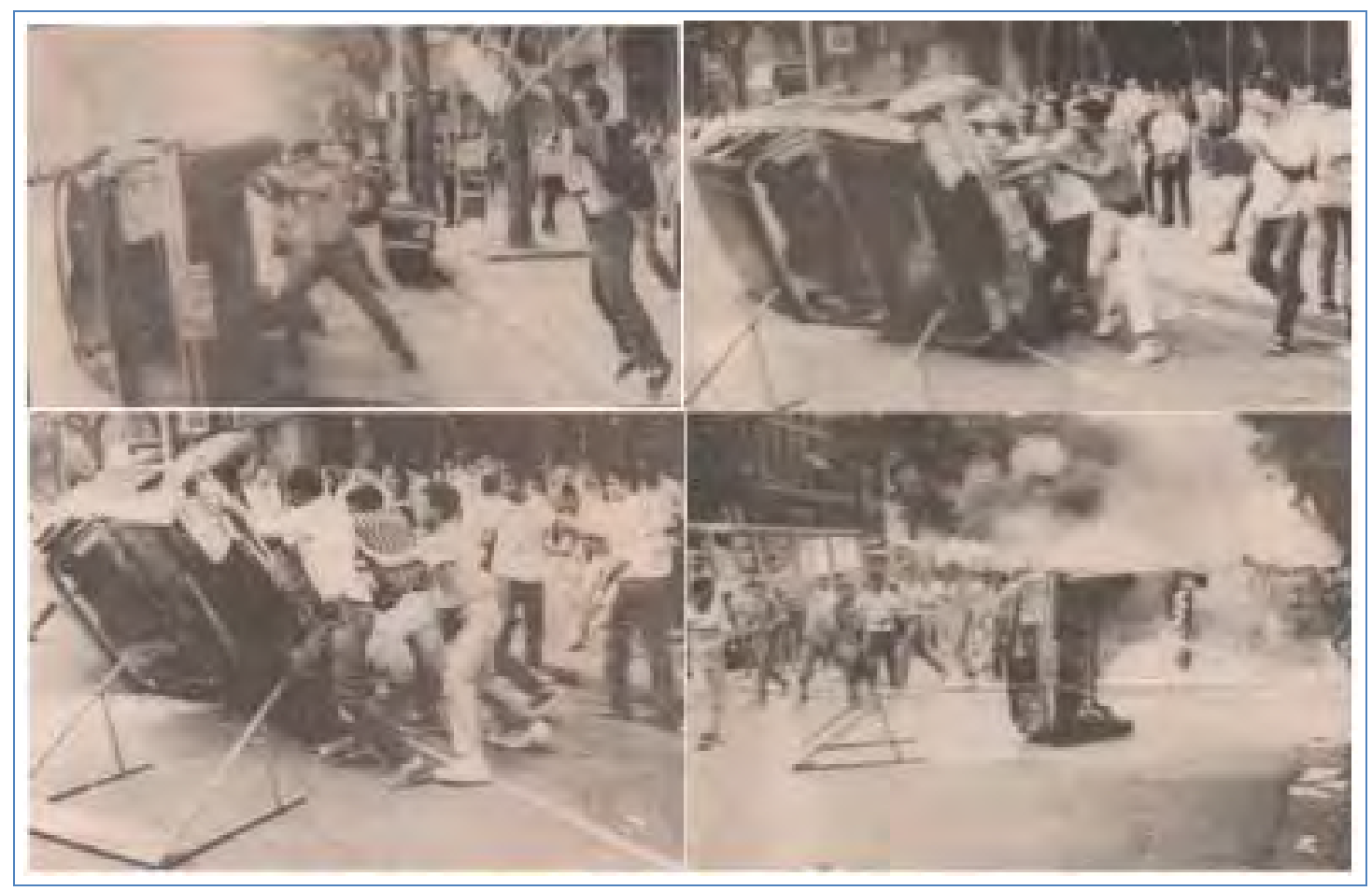


identificado com o carnaval carioca de rua (fotos 5.1, 5.2 e 5.3). Uma segunda leitura diz respeito à atribuição de valor político ao espaço público visual pela ocupação popular, afastada das ruas pela transição pactuada que decretou o fim das Diretas Já (fotos 5.4 e 5.5). Da mesma forma que as demais fotografias, todas as que integram a série de tipo 5 foram publicadas nos jornais do dia 01/07/1987.

Foto 13 - Tribuna da Imprensa

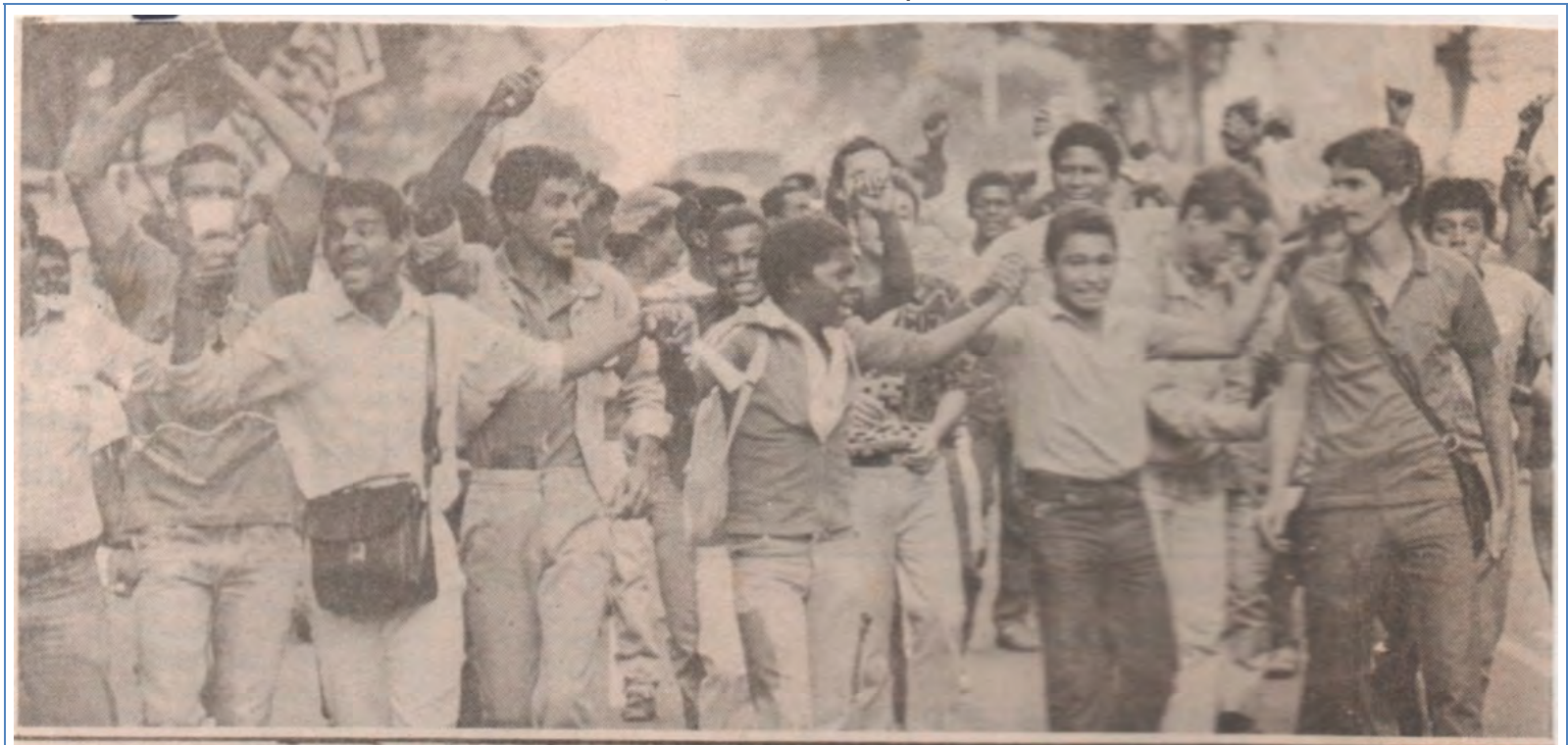

Mãos dadas, braços erguidos, o povo se uniu na arenida

Foto 14 - O Globo

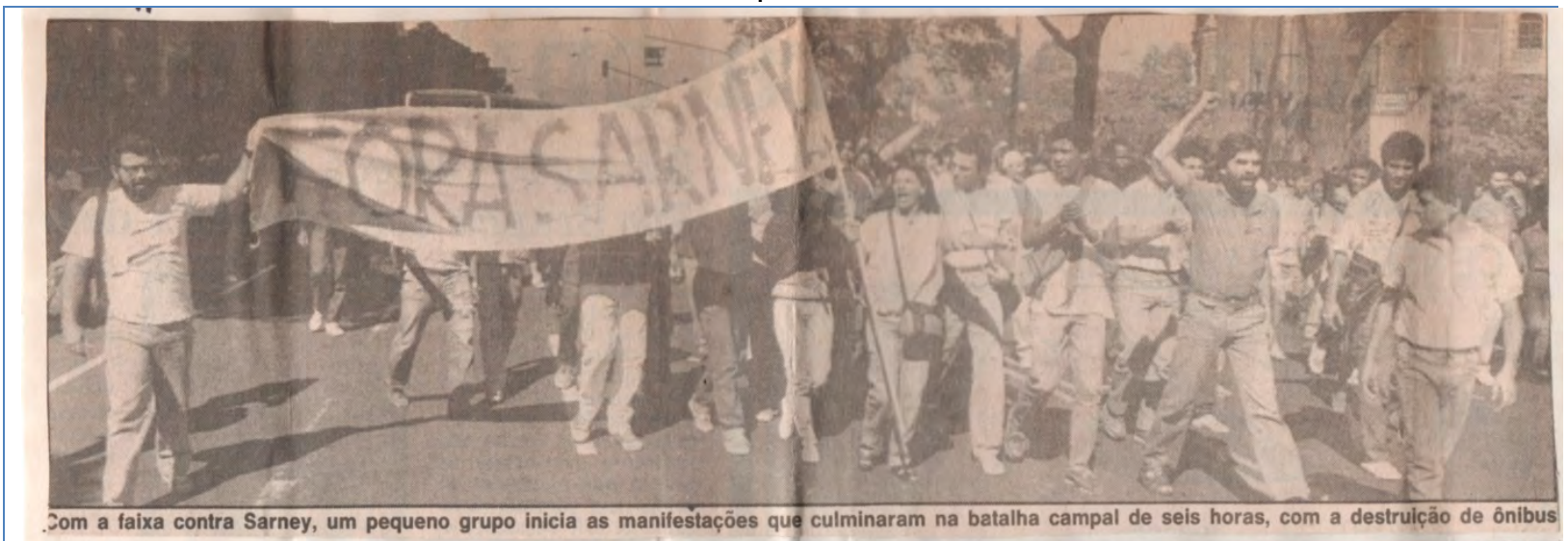


Foto 15 - Jornal do Brasil

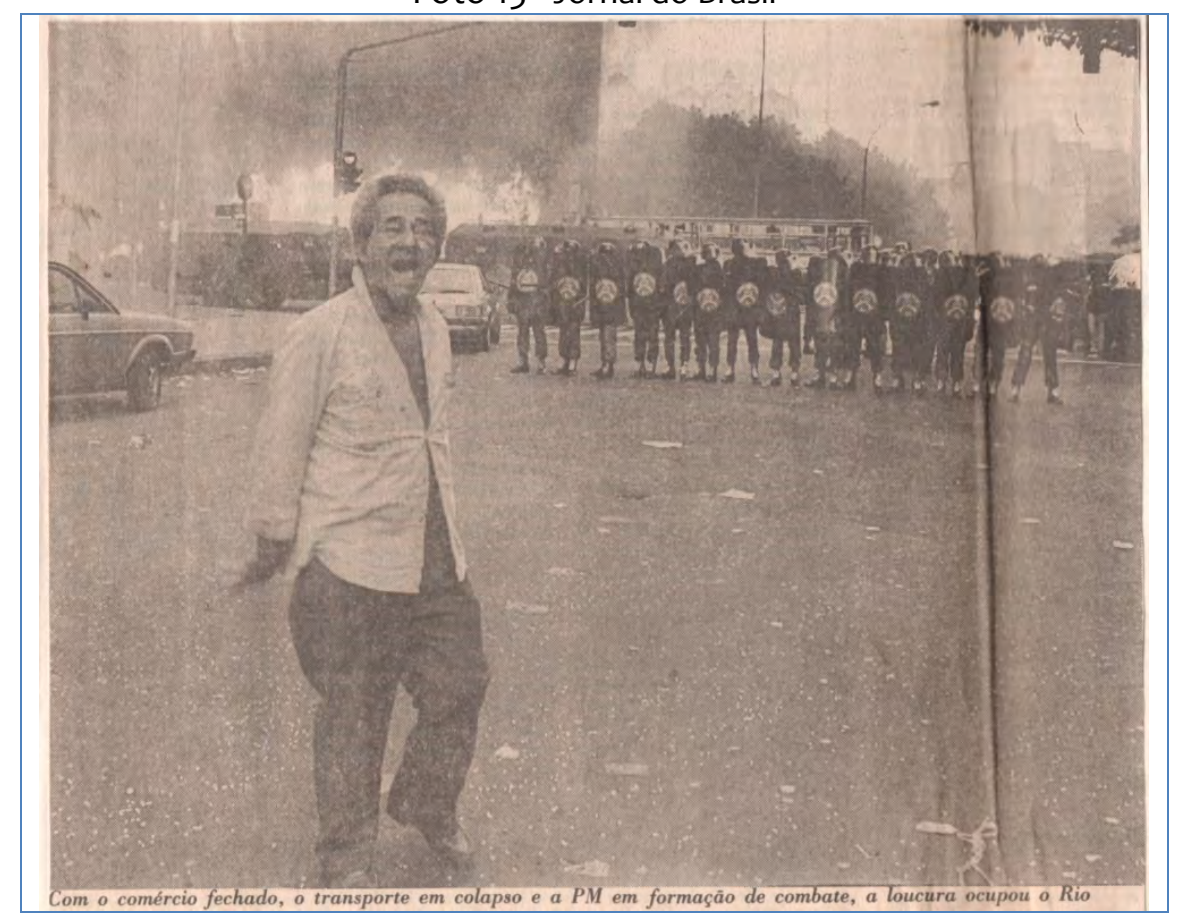

Foto 16 - O Fluminense

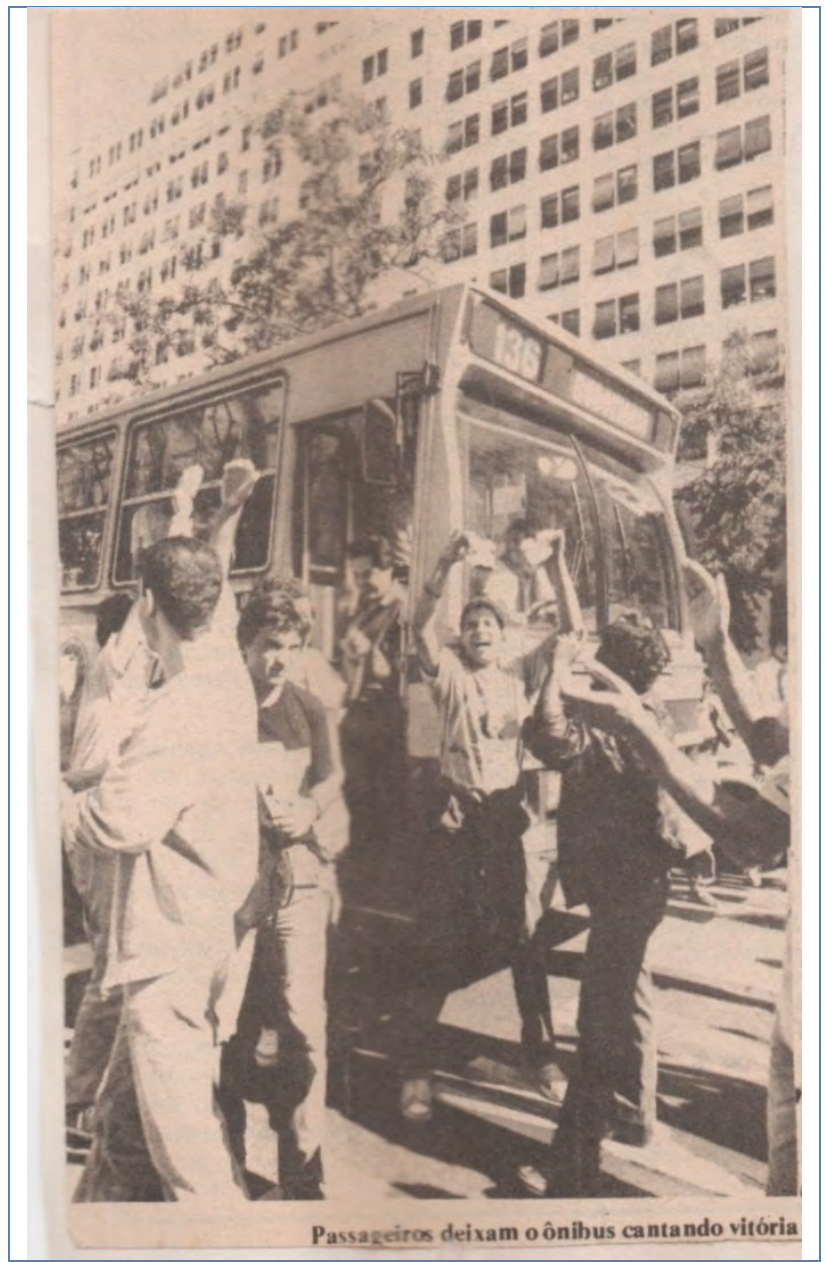




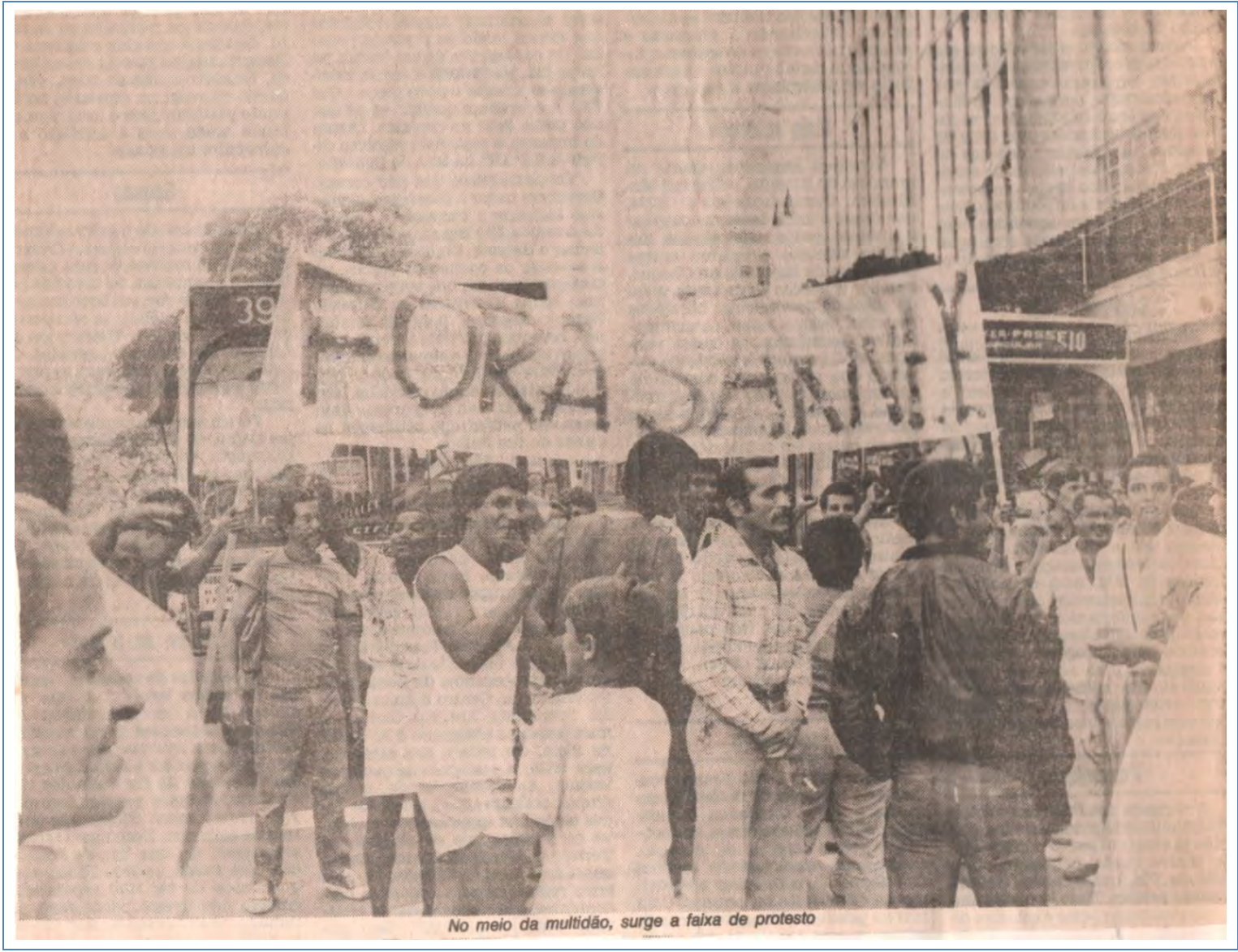

Os confrontos no Centro do Rio, iniciados no dia 30 de junho de 1987, por conta do aumento das passagens de ônibus, foram registrados pelas lentes participativas dos fotógrafos que atuavam, sobretudo, nos jornais diários. Aliás, os próprios fotógrafos encontravam-se dentro do acontecimento, na trilha prática fotográfica documental, que se delineou ao longo do século $X X$, tanto nas agências independentes, sobretudo a francesa Magnum, quanto nas redações dos jornais diários e revistas semanais (MAUAD, 2008b, SOUSA, 2000).

A análise das séries de imagens evidencia repertórios visuais acionados para a tradução do acontecimento em cenas. Em cenas de ação, reação, repressão, salvação, destruição, oposição, manifestação e ocupação, o acontecimento do dia 30 de junho de 1987 conformou o espaço público visual do acontecimento. Esse fenômeno definiu tanto a persistência de sua memória quanto a conversão crítica das imagens fotográficas dos jornais diários pela análise histórica. 


\section{Caminhos possíveis}

A história da fotografia, ou melhor, a história fotográfica de que se ocuparam Benjamin e Kracauer (2009), em suas considerações incluídas nesse texto, possibilita que a análise histórica compreenda as fotografias como suportes de prática sociais (MENESES, 2005). Nesse sentido, as fotografias produzidas no dia 30 de junho de 1987 apontam dois caminhos possíveis e complementares para a epistemologia do tempo presente.

Um primeiro nível diz respeito à própria condição histórica da prática fotográfica que promoveu a cobertura do acontecimento de modo a configurar um espaço público visual na imprensa diária. Vale ressaltar que nos anos 1980 a fotografia se afirmaria no Brasil, tanto do ponto de vista profissional, com o reconhecimento de uma série de direitos trabalhistas para a categoria dos repórteres fotográficos, quanto do ponto de vista político, pela presença da fotografia das agências independentes na cena pública da retomada dos direitos políticos, como ainda pelo reconhecimento da prática fotográfica como parte dos mundos da arte, com implantação, em 1982, na FUNARTE, de uma proposta nacional para a atividade fotográfica (MAUAD; LOUZADA; SOUZA JUNIOR, 2014).

O outro caminho posiciona a experiência fotográfica, que resulta do acontecimento, como uma possível via para se enfrentar aquilo que Nora identificou como o "paradoxo do acontecimento" no mundo contemporâneo. Ao traduzir o acontecimento em cenas, a experiência fotográfica encapsula o fluxo contínuo do presente e transforma o instante no ponto de encontro entre múltiplos tempos. Os acontecimentos históricos observados por meio das imagens e suas trajetórias, da mesma forma que as datas de Bosi (1992), se tornariam pontas de icebergs.

No mar da História há que se navegar com atenção. 


\section{Referências}

\section{Jornais diários}

Estado de S.Paulo, São Paulo, $1^{\circ}$ de julho de 1987

Folha de S.Paulo, São Paulo, $1^{\circ}$ de julho de 1987

Jornal do Brasil, Rio de Janeiro, $1^{\circ}$ de julho de 1987

O Dia, Rio de Janeiro, $1^{\circ}$ de julho de 1987

O Fluminense, Rio de Janeiro, $1^{\circ}$ de julho de 1987

O Globo, Rio de Janeiro, $1^{\circ}$ de julho de 1987

Tribuna da Imprensa, Rio de Janeiro, $1^{\circ}$ de julho de 1987

Última Hora, Rio de Janeiro, $1^{\circ}$ de julho de 1987

\section{Bibliográficas}

ASSIS, Charleston José de Sousa. Grande imprensa e lutas sociais: os jornais e os populares na revolta popular carioca de 1987. In: ENCONTRO REGIONAL DA ANPUH-RIO - MEMÓRIA E PATRIMÔNIO, XIV, Rio de Janeiro, 19 a 23 de julho, 2010. Anais eletrônicos... Rio de Janeiro: ANPUH-RIO, 2010. Disponível em: <WwW.encontro2010.rj.anpuh.org/arquivo/download?ID_ARQUIVO>. Acesso em: 22/01/2016 -

AZOULAY, Ariella. The civil contract of photography. Cambridge: MIT Press, 2008.

AZOULAY, Ariella. Civil imagination. London: Verso, 2012.

BELTING, Hans. Antropología de la imágen, Buenos Aires: Katz Editores, 2012.

BENJAMIN, Walter. Pequena História da Fotografia (1931) e teses sobre a história (1940). In: BENJAMIN, Walter. Obras escolhidas I. São Paulo: Brasiliense, 1987.

BENJAMIN, Walter. Sobre la fotografia, edição e tradução de José Muñoz Millanes, Valência: Ed. Pre-Textos, 2008.

BOSI, Alfredo. O tempo e os tempos. In: Tempo e História. SP: Cia das Letras, 1992.

GINZBURG, Carlo. O fio e os rastros: verdadeiro, falso, fictício. São Paulo: Companhia das Letras, 2008. 
HARIMAN, Robert; LUCAITES, John Louis. No caption needed. Chicago: University of Chicago Press, 2007

KNAUSS, Paulo. O desafio de fazer história com imagens: arte e cultura visual. ArtCultura, Uberlândia, v. 8, n. 12, p. 97-115, jan.-jun. 2006.

KNAUSS, Paulo. Aproximações disciplinares: história, arte e imagem. Anos 90, Porto Alegre, v. 15, n. 28, p.151-168, dez. 2008

KRACAUER, S. Ornamento da massa: ensaios, São Paulo: Cosac Naify, 2009

KRACAUER, S. Photography, IN: TRACHETENBERG, Alan (Ed.). Classic essays on photography, New Haven: Leete's Island Books, 1980, p. 245-268

LISSOVSKY, Mauricio. 10 proposições acerca do future da fotografia e dos fotógrafos do future. Revista FACOM, n. 23, $1^{\circ}$ semestre, p. 4-15, 2011.

LISSOVSKY, Mauricio. Pausas do destino: teoria, arte e história da fotografia. Rio de Janeiro: MauadX, 2014.

LUGON, Olivier. L'anonymat d'auter. In: Le statut de l'auteur dans l'image documentaire: signature du neuter. Paris: Jeau de Paume, 2006. Document 3, p.4-13.

MAUAD, Ana M. Como nascem as imagens? um estudo de história visual. História: Questões \& Debates, Curitiba, n. 61, jul./dez., 2014a, p. 105-135

MAUAD, Ana M. Committed eye: photographs oral sources and historical Narrative. In: Oral history and photography.1 ed.Nova York : Palgrave Macmillan, 2011, v.1, p. 223-239.

MAUAD, Ana M.; LOUZADA, Silvana; SOUZA Junior, Luciano Gomes. Anos 1980, afirmação de uma fotografia brasileira. IN: QUADRAT, Samantha (Org.) Não foi tempo perdido, os anos 80 em debate. Rio de Janeiro: 7Letras: FAPERJ, 2014b, p. 186-209.

MAUAD, Ana M. Foto-ícones, a história por detrás das imagens? considerações sobre a narratividade das imagens técnicas. In: Imagens da história. 1. ed. São Paulo : Hucitec, 2008a, v.1, p. 33-66.

MAUAD, Ana M. Uma disputa, uma perda e uma vitória: fotografia e a produção do acontecimento histórico na imprensa ilustrada dos anos 1950. In: Comunicação e história: interfaces e novas abordagens. 1 ed. Rio de Janeiro: Mauad, 2008b.

MAUAD, Ana M. Sobre as imagens na história, um balanço de conceitos e perspectivas. Revista Maracanan, n.14, Janeiro 2016, no prelo.

MENESES, Ulpiano T. Bezerra de. Fontes visuais, cultura visual, história visual: balanço 
provisório, propostas cautelares. Revista Brasileira de História, v. 23, n. 45, p.00-00, julho de 2003.

MENESES, UIpiano T. Bezerra de. Rumo a uma história visual. In: MARTINS, José de Souza, ECKERT, Cornélia; NOVAES, Sylvia Caiuby (Org.), o imaginário e o poético nas ciências sociais. Bauru: EDUSC, 2005

NORA, Pierre. O retorno do Fato. In: LE GOFF, J.; ORA, P. (Org.). História: novos problemas. Rio de Janeiro: Liv. Francisco Alves, $2^{\mathrm{a}}$ ed., 1979, p. 179-193

PÔRTO Jr., Gilson (Org.). História do tempo presente, Bauru, SP: EDUSC, 2007

QUADRAT, Samantha (Org.) Não foi tempo perdido: os anos 80 em debate, Rio de Janeiro: 7Letras: FAPERJ, 2014

SOUSA, Jorge Pedro. Uma história crítica do fotojornalismo ocidental. Chapecó: Grifos, Florianópolis: Letras Contemporâneas, 2000.

STIMSON, Blake. The pivot of the world: photography and its nation. Massachusetts: MIT Press, 2007.

VARELLA, F. et. al (Orgs.). Tempo presente e usos do passado. Rio de Janeiro: FGV Editora, 2012. 